\title{
The effect of a livelihoods intervention in an urban slum in India: \\ Do vocational counseling and training alter the attitudes and behavior of adolescent girls?
}

\author{
Barbara Mensch \\ Population Council \\ Monica J. Grant \\ Population Council \\ Mary Philip Sebastian \\ Population Council \\ Paul C. Hewett \\ Population Council \\ Dale Huntington
}

Follow this and additional works at: https://knowledgecommons.popcouncil.org/departments_sbsr-pgy

Part of the Educational Sociology Commons, Family, Life Course, and Society Commons, Gender Equity in Education Commons, International Public Health Commons, Rural Sociology Commons, and the Vocational Education Commons

How does access to this work benefit you? Let us know!

\section{Recommended Citation}

Mensch, Barbara, Monica J. Grant, Mary Philip Sebastian, Paul C. Hewett, and Dale Huntington. 2004. "The effect of a livelihoods intervention in an urban slum in India: Do vocational counseling and training alter the attitudes and behavior of adolescent girls?" Policy Research Division Working Paper no. 194. New York: Population Council. 


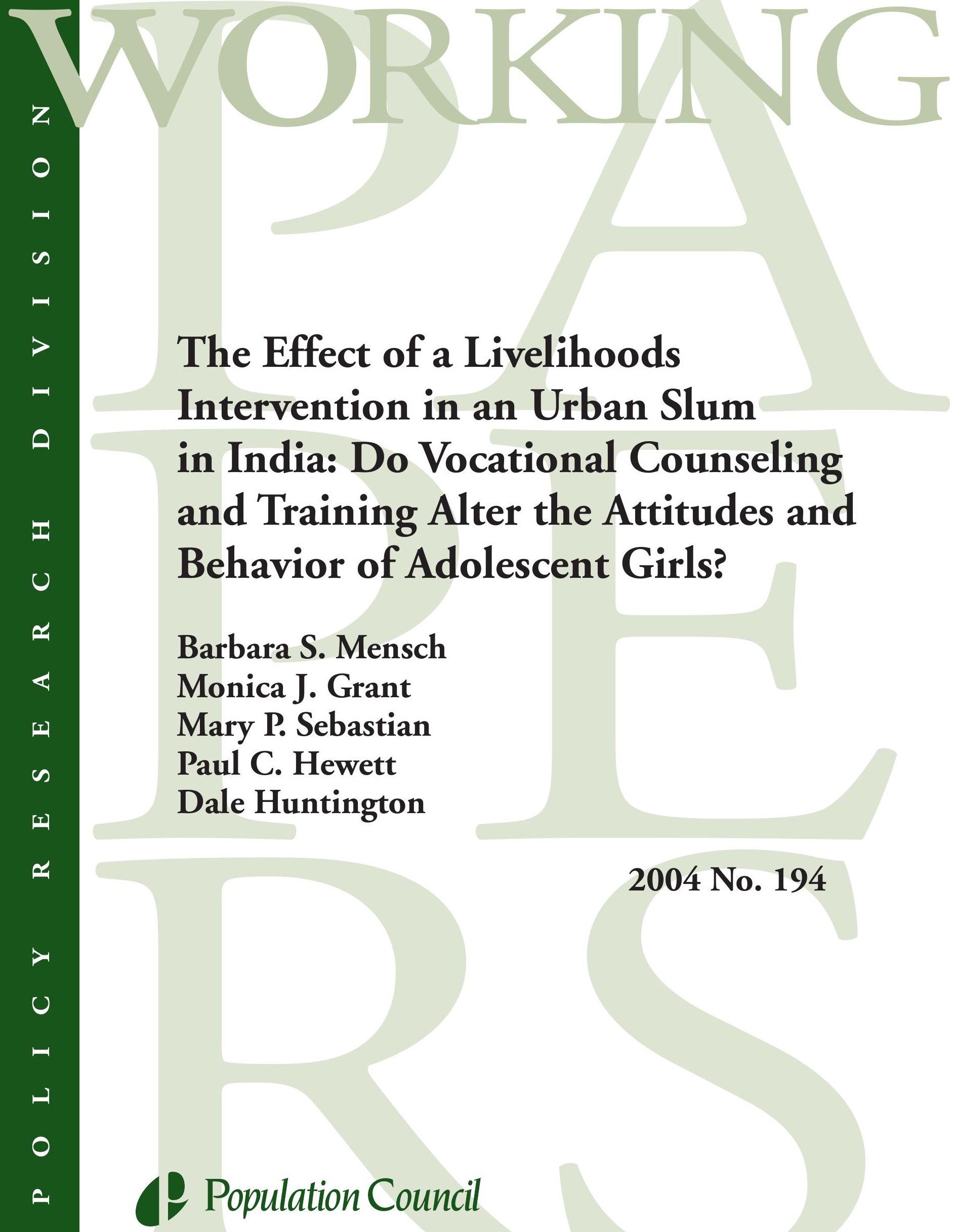




\title{
The Effect of a Livelihoods Intervention in an Urban Slum in India: Do Vocational Counseling and Training Alter the Attitudes and Behavior of Adolescent Girls?
}

\author{
Barbara S. Mensch, Monica J. Grant, Mary P. Sebastian, \\ Paul C. Hewett, and Dale Huntington
}

Barbara S. Mensch is Senior Associate, Monica J. Grant is Research Coordinator, and Paul C. Hewett is Research Associate, Policy Research Division, Population Council. Mary P. Sebastian is Program Officer, Population Council, New Delhi. Dale Huntington is Responsible Officer, Health Sector Reform, Department of Reproductive Health and Research, World Health Organization.

Acknowledgments: This study was made possible through support provided by the Andrew W. Mellon Foundation, the Department for International Development (DFID), UK, and the Office of Population, Health and Nutrition of the United States Agency for International Development (USAID).

An earlier version of this paper was presented at the Population Association of America Annual Meeting in Boston, April 2004.

This material may not be reproduced without written permission from the authors. For a list of Policy Research Division Working Papers, including those that are currently available for downloading in PDF format, see www.popcouncil.org/publications/wp/prd/rdwplist.html.

\section{(C) 2004 The Population Council, Inc.}




\begin{abstract}
This paper examines whether an experimental intervention for girls aged 14-19 that provided reproductive health information, vocational counseling and training, and assistance with opening savings accounts in slum areas of Allahabad in Uttar Pradesh, India had an effect on their attitudes and behaviors. A quasi-experimental pre- and posttest design was used in which adolescent girls aged 14-19 residing in the interventionarea slums were compared with girls of the same age residing in control-area slums. Although the livelihoods program was acceptable to parents and feasible to implement, the project had only a minimal impact on the behavior and attitudes of adolescent girls in the experimental slums. The greatest changes between the baseline and the endline surveys were found in those outcomes that most closely reflected the content of the intervention. Girls exposed to the intervention were significantly more likely to have knowledge of safe spaces, be a member of a group, score higher on the social skills index, be informed about reproductive health, and spend time on leisure activities than were the matched control respondents. No effect was found on gender-role attitudes, mobility, self-esteem, work expectations, or on number of hours visiting friends, performing domestic chores, or engaging in labor-market work.
\end{abstract}


To the extent that the population community has been concerned with adolescents in developing countries, attention has been focused on their sexual and reproductive behavior. The rise in the prevalence of sexually transmitted infections, in particular HIV, has driven not only the research agenda but also policies and programs. With adolescence increasingly being viewed as "a period of critical capability-building ${ }^{1}$ and heightened vulnerability" (Mensch et al. 1998:77), policymakers and program planners have begun to broaden their efforts on behalf of young women. In this spirit, livelihoods initiatives have been developed for adolescent girls. As broadly conceived, the "livelihoods approach" to adolescent programming attempts to develop technical and life skills while influencing social networks and improving access to savings, loans, and markets. In settings where young women's movements are restricted to the domestic arena, providing safe spaces outside the home is expected to promote mobility and independence and give girls greater visibility in the community. By increasing contact with others outside the family, including both female peers and adults who can function as mentors, social and interpersonal capacities may be advanced and communication skills developed. Finally, livelihood programs offer acceptable settings for supplying information about reproductive health (Bruce 2002; Population Council and UNICEF 2003).

The rationale for developing livelihood programs for girls is particularly salient in India, where half of women aged 20-24 are married by age 18, where women's autonomy, as measured by freedom of movement, is limited, and where domestic violence, particularly that perpetrated by husbands against wives, is condoned (IIPS and ORC Macro 2000).

Although a wide variety of livelihood programs and projects for women exists in India, access is generally restricted to married women. The few nascent experiments involving unmarried adolescent girls are limited in scale and have not been evaluated. When adolescent girls are involved in income-generating activities, they generally assist their mothers in home-based work for which they may or may not be remunerated. Moreover, adolescent girls are not participants in savings and credit programs (Sebstad and Singh 1998).

Programmatic initiatives that prepare girls in India for future livelihoods and foster their mobility are rare, and evaluations of such programs are even less common. In this paper, we examine whether an experimental intervention for girls aged 14-19 that provided vocational counseling and training and assistance with opening savings accounts in slum areas of Allahabad in Uttar Pradesh, India:

- increased physical mobility and contact with individuals outside the family as well as awareness of safe places for girls to congregate;

- increased self-efficacy;

- increased reproductive health knowledge;

- altered work aspirations and encouraged more progressive gender role norms; and

- reduced time spent on domestic tasks and increased time spent on productive tasks. 
The evaluation uses a quasi-experimental pre- and post-test design that compares adolescent girls who participated in the intervention with those residing in a control area.

\section{LITERATURE REVIEW}

Livelihoods initiatives are increasingly being promoted for adolescent girls. The effect of these programs on attitudes and behavior has not been rigorously investigated, however, although much speculation exists about their potential benefits. For example, CEDPA, a United States-based nongovernmental organization (NGO) that has been at the forefront of the livelihoods movement for adolescent girls, has developed "The Better Life Options Program," an integrated curriculum that includes literacy training, family life education, vocational skills training, and reproductive health services. More than 10,000 females aged 15-26 in three Indian states have participated. The evaluation consisted of a post-test-only control group design. Lacking a baseline survey, such a design cannot detect change in behavior. Furthermore, the researchers did not address the possibility that those who participated in the program might be selective for particular characteristics, thereby potentially biasing the results in favor of finding significant effects (CEDPA 2001). More recent pilot studies of livelihoods interventions for adolescents have been designed with quasi-experimental pre- and post-test designs. The University of California, San Francisco-Women's Global Health Imperative is currently working with Samuha, a community-based NGO in India, to develop an intervention for adolescent girls in Bangalore and urban Karnataka. This project focuses on building the economic resources and reproductive health knowledge of adolescents in order to increase their current and future bargaining power in sexual relationships and reduce their HIV susceptibility. Research in the pilot phase has focused on participant observation, intensive qualitative interviews with pilot participants and members of the community, and process documentation of the pilot itself. The next phase of the project will involve a pre- and post-intervention cohort study of participants and a control group (Tantri 2004).

The literature on the effect of work on the lives of young women is scarcely more extensive than the literature on livelihoods and is similarly speculative (see Mensch et al. 1998). Legitimate income-generating work is said to transform girls' adolescent experience by providing them with a degree of autonomy and freedom from traditional gender roles. Most important, such work is believed to reframe the second decade of girls' lives from a period devoted to preparation for marriage and childbearing to a time when they can develop as individuals and gain knowledge and skills that are the foundation for a more productive adulthood. Work is thought to provide to girls, who are often confined to the home and given heavy domestic responsibilities, an alternative source of social status, networks, and peer-support groups outside the family. Girls who contribute income to their households are likely to have more say in the marriage process. Analyses of data from the World Fertility Surveys in which women were asked about the timing of work relative to marriage indicate that, controlling for education, women who worked prior to marriage wed later than those who did not work. Although those who held jobs in the modern sector were married latest, even those who worked in traditional occupations married later than those who did not work. These findings suggest not only 
that a link between labor-force participation and age at marriage is the result of delayed marriage increasing the likelihood of employment, but also that women who work postpone marriage (United Nations 1987). ${ }^{2}$ In addition, assets brought to marriage affect bargaining power within marriage (Quisumbing and Hallman 2003). Although this bargaining power influences options to terminate a marriage, it also extends, presumably, to control over sexual behavior and childbearing.

More than a quarter century ago, Dixon (1978:132) recognized the potential demographic benefits of wage-earning work for young women in South Asia and called for efforts to "recruit unmarried girls and young married women in their early childbearing years [for employment outside the home] so that their new status can have a maximum potential impact on delaying marriage, delaying their first birth, and spacing and limiting additional births." Although we lack adequate data concerning trends in adolescents' labor-force participation, to the best of our knowledge opportunities for formal, remunerated work have barely grown for girls and remain much less common than for boys. Thus, we can only speculate about the implications of such opportunities for girls' social and economic well-being. Moreover, natural employment experiments are scarce; only a few examples of these are found in the developing world. Research conducted in Bangladesh supports the view that income-generating employment can transform the lives of girls in settings where historically their social status has been low. Substantial delays in marriage have been observed among adolescent girls employed in garment factories (Amin et al. 1998).

\section{SETTING}

The project examined here was conducted in slum areas of Allahabad in the northern state of Uttar Pradesh, the most populous of India's 28 states. Allahabad, located approximately 600 kilometers from Delhi, is the sixth-largest city in Uttar Pradesh, with nearly one million residents according to the 2001 census (see www.census.india.net). The city, which is situated at the confluence of two sacred rivers, the Yamuna and the Ganges, is best known as the site of the Kumbh Mela, a Hindu pilgrimage held every 12 years.

Allahabad is said to be the "fastest growing city" in the state of Uttar Pradesh (CORT 2000:2), with a commensurate increase in the slum population. The lack of livelihood opportunities in the rural areas of Allahabad district has driven many families to move to Allahabad city. Rural migrants live in overcrowded slums with poor hygiene and sanitation, and they experience the many social problems and vulnerabilities associated with extreme urban poverty (Kantor and Nair 2003). In 1999, CARE India, one of the largest NGOs working in the country, designed a five-year project to improve the reproductive health of approximately 100,000 Allahabad slum residents (CORT 2000:2).

\section{STUDY DESIGN}

Because the staff at CARE had considerable experience in Allahabad and because of their interest in developing an adolescent livelihoods program, the Population Council 
invited them to collaborate on the implementation of the intervention. Allahabad's 143 slum areas had been divided by CARE staff into seven wards for program and research purposes. For the project, two comparable wards were selected purposively according to the CARE project schedule; one was randomly assigned as the experimental site and the other as the control site. Five slum areas within the experimental ward were randomly selected as project sites, and nine smaller areas were chosen in the control ward. ${ }^{3}$ In order to evaluate the intervention, a quasi-experimental pre- and post-test design was used in which adolescent girls aged 14-19 residing in the intervention slums were compared with girls of the same age residing in control-area slums.

\section{LIVELIHOODS INTERVENTION}

The intervention, which began in 2001, integrated livelihood activities for adolescent girls aged 14-19 into CARE's reproductive health program for slum dwellers, the "Action for Slum Dwellers' Reproductive Health, Allahabad" (ASRHA). The underlying premise of the intervention was that multiple benefits can accrue from activities related to reproductive health education when community participation and capacity-building activities are included.

At the onset of the project, literate 14-19-year-old girls who had their parents' permission were identified and trained to be peer educators. The peer educators attended a six-day reproductive health training course and a two-day peer-education training course to help them become more effective communicators and facilitators for discussions about vocational training opportunities and savings account formation. Emphasis was placed on providing information about reproductive health and livelihoods and on communication and group-formation skills. The goal was to train peer educators to encourage girls to participate actively in the group discussions. Each peer educator was expected to visit every household in her locality and invite all eligible young women to participate in the project. When approximately 20 girls had been given permission to participate, a group was formed that met once a week at the home of a peer educator. Participants residing in the experimental slums received reproductive health training sessions, vocational counseling, savings formation information, and follow-up support from a peer educator. Although the vocational counseling and savings components were integrated with the reproductive health lessons, the vocational training sessions were held after the completion of the reproductive health classes and were open only to those participants who had maintained good attendance.

The control group's eligible adolescents participated in the ASRHA reproductive health activities but did not receive vocational counseling, training, or savings information. Although the intention of the program was to provide the same reproductive health component in both the control and the experimental slums, CARE staff were more likely to supervise activities in the experimental slums. Moreover, unlike the girls in the control slums, the girls in the experimental slums were regular attendees at the reproductive health sessions because participation in vocational counseling was contingent on attendance and because parents were more likely to grant permission to attend regularly given the interest in the vocational activities. 
The group sessions concerning reproductive health, which included discussions about puberty, menstruation, reproductive biology, pregnancy, contraception, sexually transmitted infections, and age at marriage, began in the experimental sites in June 2001 and continued through the spring of $2002 .^{4}$

Following the completion of the reproductive health curriculum, vocational counseling was offered, which emphasized the importance of paid work and savings. Minimal discussion of gender roles was included. Using flip books that contained vocational flash cards with a description of courses available, the counselors provided detailed information about short-term, nonformal training courses available in the vicinity, including courses offered by government institutes and NGOs, as well as those organized specifically by the project. Interested girls were encouraged to participate in several ways: They were assisted in filling out the application forms; and project staff spoke with one of their parents about the course and about contributing to payment of course fees.

Vocational courses began in the fall of 2001, when the first round of peer groups completed the reproductive health curriculum, and they continued through June 2002 with the project staff providing follow-up support until December 2002. The selection of courses offered was based on the number of girls interested; a minimum of ten girls was required for a course to be offered. Courses arranged by the project included tailoring (requiring basic literacy skills that some girls did not possess), mehndi (painting of hands or feet), creative painting, dhari (rug weaving), mending and embroidery, candle making, silver ornament and link making, pot decoration, crochet, jute doll making, basic cooking, personal grooming, and fabric painting. The project also made arrangements for older girls (18 years and older) to attend government-run courses, for example, bee keeping, food preservation, jute craft, macramé, cooking, carpet weaving, and block printing. Because many girls wanted to participate in more than one course, the project set a limit of five courses per girl in order to allow as many newcomers an opportunity as possible.

Almost all of the intervention participants attended a class in either mehndi or creative painting, held in the home of the peer educator. Subsequent training sessions for other courses were held at a central training center that required a brief commute. Although the girls traveled to the center as a group, parental permission was required. As parents became accustomed to their daughters' participation, girls were able to attend courses that required commuting on their own, for example, classes run by the government.

After the training, some materials were required for the production of handicrafts at home. Initially the project provided some of this capital investment (for example, handlooms for dhari weaving classes and materials used for sewing). Participants contributed a small amount toward the purchase of the raw materials required for their courses.

Although training in handicrafts might appear to provide the girls little in the way of economic return, research by Liebl and Roy (2003) indicates that the export of handicrafts has increased considerably in India in recent years. Indeed, handicrafts' share 
in India's manufacturing exports is estimated to have risen from 2 percent in 1987 to 5 percent in 1999. From 1990 to 1999, the number of people employed in the handicraftsexport sector more than doubled, from around 4.3 million to 9.6 million.

Concurrently with the vocational skills training, counseling and assistance were provided for creating savings accounts at banks or post offices. Most of the new accounts were opened at post offices rather than banks, because the post office procedures were simpler and the initial deposit required less money. Although interest in opening savings accounts was considerable, significant obstacles arose that made continued operation of the accounts difficult. Post office staff, who were all male, frequently expressed their lack of enthusiasm for working with adolescent girls. They would chastise the girls for disturbing their work and sometimes sent them away to return another day. Some even harassed the girls. ${ }^{5}$

A total of 27 groups were formed by the peer educators. Of the 525 girls who took part in the reproductive health information sessions, all but 38 completed at least one vocational course. Only 250 girls opened savings accounts, presumably because of the difficulties they had with the post office staff.

\section{Data Collection}

In light of the problems encountered in conducting a longitudinal survey of adolescents in the slum areas, we discuss the issues related to data collection at length below, specifically (1) the differences in coverage of the slum areas between the baseline and endline surveys; (2) the differences between respondents interviewed at one round only and those who were followed up; and (3) inconsistent responses to the same questions for those who were followed up. All of these issues have implications for the evaluation of the livelihoods intervention.

\section{Baseline survey}

Data collection for the baseline survey took place between April and June 2001, prior to the start-up of the intervention. The Centre for Operations Research and Training (CORT), the organization responsible for the National Family Health Survey (the Indian Demographic and Health Survey) in Uttar Pradesh, conducted the fieldwork. All adolescents aged 14-19 years who were living in the study areas for at least one year were specified for inclusion in the baseline survey-both sexes, married and unmarried, in school and out of school. A mapping exercise was conducted to determine the boundaries of the slum areas and arrive at a functional definition of a household. Although the boundaries of the slums were defined on government maps, these boundaries had to be updated and verified with local government officials at the time of the survey. Some areas defined as slums contained the homes of relatively better-off households, especially those along the boundary lines, which reinforced the need for verification within the municipality. Many structures were temporary shelters for migrant laborers, and others were dwellings that were locked and appeared to be abandoned. Therefore, a household was defined as a dwelling that was inhabited within the past four to six months prior to the survey. 
A "census" of the selected slums, conducted by CORT, identified 6,401 households; contact was made with an occupant in 6,086 of these households. ${ }^{6}$ Of the households, 2,452 contained eligible adolescents aged 14-19. Of the 4,292 young people in these households, 3,199 were interviewed (Table 1). Response rates in the experimental and control areas were the same, with approximately 75 percent of eligible young people completing the baseline survey ( 82 percent of females and 68 percent of males; not shown).

Information about the following domains was collected from each of the adolescents:

- Demographic data

- Family background

- Respondent's education and training history

- Livelihood and employment history

- Time-use pattern

- Mobility, autonomy, gender-role attitudes, and behavior

- Knowledge of reproductive health

- Knowledge of contraceptive methods

- Marriage process

- Reproductive history

- Self-efficacy

- Connectedness and friendship

- Alcohol and drug use

The baseline survey clearly indicated the cultural appropriateness of the intervention, particularly as indicated by the differences between boys and girls with respect to mobility, time-use patterns, and savings and work experience:

- Approximately half of the girls indicated that they had not traveled outside of Allahabad during the past six months, compared with only about one-fourth of the boys.

- Girls were much more likely than boys to report that they needed to seek permission to visit outside of their homes; both boys and girls reported that there were no places in the community where unmarried girls could safely congregate for any purpose, a finding that reflects local norms governing unmarried girls' use of public space.

- Girls reported spending more than four times as many hours as boys on chores (4.3 and 1.0 hours, respectively).

- The proportion of boys who reported that they had ever worked for pay was five times greater than that of girls (34.3 percent of boys vs. 6.0 percent of girls).

- Despite the fact that girls were much less likely to work for pay, they were more inclined to save; 54 percent of the girls and 26 percent of the boys had some savings, and of those who saved, 7 percent of girls and 28 percent of boys had money in a savings account. 


\section{Endline survey}

Although the baseline results were compelling, analysis of the data indicated that the survey underrepresented married adolescent girls; only 2 percent of young women interviewed reported ever having been married, whereas in the 1998-99 National Family Health Survey, 16 percent of women aged 15-19 living in urban areas reported being currently married (IIPS and ORC Macro 2000). The small proportion of girls interviewed for this study who reported being married is an outcome of several factors. Because the legal age of marriage for females is 18 , married girls aged 18 or 19 often may not consider themselves or be considered adolescents, and hence are not included in a listing of adolescents living in a household. This problem was compounded in the baseline survey because, unbeknownst to the project investigators, the Hindi word for adolescent or youth-kishor $(i)$ — used in the survey implies that the person referred to is unmarried. Another contributing factor may be the desire to hide an illegal underage marriage, either out of shame or out of fear of legal repercussions. Finally, no effort was made to locate married young women who had moved to their conjugal households or to interview married women in the households selected for the survey.

Given the experience with the baseline survey, considerable efforts were made to improve coverage in the endline survey, which was conducted in the spring of 2003. In the 6,856 households that were contacted, 6,547 rosters were completed. Of these households, 3,853 included eligible adolescents, 1,401 more than had been identified in the baseline survey. The household roster identified 7,572 eligible young people; of these, 6,148 completed the survey, 3,075 of whom were girls.

At the endline, the response rates of males and females were similar; conscious of the lower response rates of boys at the baseline, interviewers paid extra attention to scheduling interviews when young men were more likely to be available. A difference in the response rates between the control and experimental areas was found, however ( 88 and 77 percent, respectively).

In the endline survey, 4,306 young people were interviewed who had not been included in the baseline, a disconcertingly large number. ${ }^{7}$ What explains the 57 percent increase in identified households with eligible adolescents at the endline? Although 15 joint households from the baseline split to become 32 nuclear households in the endline, this split barely accounts for any of the increase in the number of households. We can only speculate to what degree the increase is attributable to the combined effects of inmigration, better coverage by the endline survey, and improved efforts to identify eligible young people within households.

One reason for the vast increase in the sample size for the endline may be that the Allahabad slums are an area of significant population flux; perhaps a large number of young people moved into the city in the interval between the baseline and the endline surveys. To explore this possibility, each female endline respondent ${ }^{8}$ was categorized by her baseline status (Table 2) and then further classified by how long she had lived in the slum. For those young women identified in the baseline, whether interviewed or not, approximately 90 percent responded that they had lived in the slum their entire lives (see the first two rows of Table 2). However, even the majority (73 percent) of respondents 
from newly identified households had lived in the slum their entire lives. Assuming that the responses are accurate, these are young women who should have been identified in the baseline survey; indeed, only 7 percent of all endline respondents reported that they had lived in the slum for two years or less. Although this statistic disguises any moves that households and individuals may make within the slums, it suggests that the increase in the sample from the baseline to the endline is more likely to be due to the differential diligence of the data-collection teams than to in-migration.

Of course, some of the increase in sample size may have had little to do with the efforts of the data-collection teams and more to do with the willingness of the adolescents and their parents to be interviewed. Perhaps deliberate misreporting of age occurred at the baseline because members of the community were suspicious of the survey. At the endline, young people and their parents might have become more accustomed to seeing the interview teams in the community, and, therefore, might have been more amenable to being interviewed. Moreover, some residents might have thought that by being interviewed at the endline they could be candidates for other program activities. Some young people might have identified themselves as being of an eligible age at the endline when, in fact, they were not. Thus, some of the "increased" coverage we observe in the endline might be nothing more than age misreporting either at the baseline when respondents or parents "aged" themselves out of the survey or at the endline when they reported themselves to be of eligible age.

These problems notwithstanding, the vast majority of both boys and girls identified in the baseline household roster and reidentified in the endline roster were interviewed-1,887 individuals of the total of 2,012 (not shown). Apparently, too few eligible adolescents were identified at the baseline, and even at the endline a large number of eligible young people were missed. Of the 3,199 adolescents initially interviewed at the baseline, only 1,887 were interviewed in the endline. The follow-up rate was slightly better in the experimental areas than in the control areas, at 62 and 55 percent, respectively. Girls in both areas had slightly higher follow-up rates than did boys (see Table 1). Despite the large increase in the number of young people identified and interviewed in the endline (2,949 more than at the baseline) 1,312 of those interviewed in the baseline ( 666 girls and 646 boys) were not identified in the endline household roster. ${ }^{9}$

Finally, the number of ever-married females at the endline is important to note. Twenty percent of new respondents reported that they had ever been married, a number very close to what one would expect to find. However, only 6 percent of women interviewed in both survey rounds reported ever being married at the endline when they were approximately two years older. Although this percentage represents an increase from the 2 percent interviewed at baseline, it is lower than what we anticipated, suggesting that many of the women who were lost to follow-up may have "disappeared" from the sample by marrying and moving to their conjugal households. Young women who did not marry during the inter-survey period may differ from those who married in significant ways that may influence both their participation in the intervention and their receptivity to its messages. 


\section{Comparison of baseline and endline samples}

Although coverage of the households in the sample was not nearly as complete in the baseline as it was in the endline, both survey rounds may remain representative of young people in their communities. We examine this possibility by comparing characteristics of the girls interviewed in the baseline survey with those of the girls interviewed at the endline. Because the final analysis is restricted to those girls interviewed in both rounds, we examine the differences between those interviewed in the baseline who were followed up and those who were not.

Although adolescent girls in the baseline and the endline are similar in many respects, several notable differences can be observed (see Table 3). At baseline, 23 percent of young people in the experimental slums were Muslim, compared with only 2 percent in the control slums. Although the proportion of Muslim adolescents did not change in the control areas, it declined substantially in the experimental areas, to 15 percent at endline. Likewise, between the baseline and the endline surveys, the caste distribution changed in the experimental area, becoming more similar to that of the control area.

The proportion of respondents who reported that their mother is able to read and write also differs in the baseline and endline. Although no change is seen in the reporting of father's literacy across the two rounds, the maternal literacy rate in the experimental area declined from 53 percent at the baseline to 42 percent at the endline. Moreover, the proportion of girls who ever attended school also declined in the experimental area, from 86 percent at the baseline to 81 percent at the endline (not shown). These two statistics suggest that, in some respects, the baseline and the endline surveys are not equally representative of the young people in the sampled slums. Because the endline survey was a more complete census of the population, we think that it is likely to provide a more accurate picture of the slum community than the baseline survey.

\section{Differences between those who were and were not followed up}

In addition to these distinctions between baseline and endline respondents, differences can be seen between those who were interviewed in both survey rounds and those who were not followed up. Parental literacy rates for respondents interviewed in only one round are lower than those for respondents interviewed in both rounds (as shown in Table 4). Furthermore, those who were followed up were more likely to have ever attended school than those who were not. These differences indicate a higher socioeconomic status for those who were interviewed in both rounds than for those who were not followed up. Because the sample of those followed up in both the experimental and control sites is equally unrepresentative (see Appendix Table 1), however, the effect of this difference in status on the evaluation of the intervention may not be large.

\section{Inconsistent responses}

Because the majority of questions asked in the baseline were repeated in the endline, not only can we measure the impact of the intervention by comparing responses in the two rounds for those interviewed twice, but also we can shed some light on the 
quality of data collected for questions with answers that should either remain the same in both rounds or change in an expected fashion. For mother's literacy and "ever attended school," differences are seen in reporting between the baseline and the endline (Table 4). For both measures, the endline percentages are lower, although logically they should either remain the same or increase. That is, the second and fourth columns of this table should either be the same for characteristics established prior to the baseline (for example, religion and caste) or increase for characteristics that could change (for example, parental literacy and respondent's education). Not only are there differences in literacy and school-attendance variables, but differences are also found in reporting of caste and religion, thereby raising the issue of measurement error. Although the phrasing of these questions did not change, they may not have been answered with the same reliability.

\section{ASSESSING THE EFFICACY OF THE INTERVENTION}

This evaluation is able to determine only short-term changes in the outcomes of interest because the interval between the two surveys is short; approximately 22 months elapsed between the baseline and endline interviews. Moreover, the intervention did not continue for the entire interval between surveys. The livelihoods training ended in June 2002, and follow-up support was available until December 2002, three months before the onset of data collection for the endline survey.

As is the case with a quasi-experimental design, we had no control over which adolescents residing in the experimental area participated in the intervention. Because those who participated are likely to be selective for certain characteristics that may make them more receptive to the intervention's messages, it is difficult to make any causal inferences without controlling for potential self-selection bias. Propensity score matching is a statistical technique that allows us to control for this bias by identifying those respondents from the control area who would be most likely to have participated in the intervention had they resided in the experimental area (Rosenbaum and Rubin 1983; D’Agostino 1998).

The propensity score of an individual is the conditional probability of participating in the intervention, given the baseline characteristics. ${ }^{10}$ At any given value of the propensity score, the conditional distribution of the background variables is the same for both the intervention and the control units (Rosenbaum and Rubin 1983). Therefore, by matching intervention and control respondents by their propensity scores, we can create a randomized experiment artificially. Computation of the propensity score was restricted to the 122 intervention participants and 381 respondents from the control area who were interviewed in both survey rounds. Once the propensity score was calculated, the value was used to identify a respondent from the control area with the nearest possible value to that of an intervention participant, without replacement. In other words, once a respondent was matched, she was included in the analysis sample; she could not be matched more than one time. As expected, the subjects in the intervention and matched control groups tended to have similar distributions of the baseline characteristics used to calculate the propensity score (see Table 5). 


\section{Outcome variables}

The 13 dependent variables are listed in Table 6. Consonant with the broad objectives of the livelihoods approach to adolescent programming, the dependent variables include measures of gender-role attitudes, mobility, self-efficacy, reproductive health knowledge, work expectations, and time use. ${ }^{11}$ The table lists the type of variable, the possible range, and the actual baseline and endline ranges. The dependent variables are either counts of items assessing a particular dimension; dichotomous, that is, yes/no responses to particular questions; or continuous, if a numerical response to a particular question is appropriate. Appendix Table 2 provides descriptions of the components or questions for all 13 variables.

For three measures, gender-role attitudes, self-esteem, and social skills, indexes were created. For gender roles, respondents were asked about 21 items measured by a three-point Likert scale (disagree, no opinion, agree). For self-esteem, respondents were asked about 14 items, also measured by a three-point Likert scale (disagree, neutral, agree). A principal components factor analysis (StataCorp 2003:370) was used to identify the variables that were grouped together on the same component. Once this set of variables was identified, all values for gender-role attitudes and self-esteem were coded to be positive or progressive, and each scale was summed across the items. For genderrole attitudes, eight of the 21 items were grouped together; the value of Cronbach's alpha was 0.84 , which indicates good reliability. For self-esteem, six of the 14 items were grouped together; Cronbach's alpha was 0.90 , again indicating that the measure is highly reliable. The index of social skills was purposively created from a set of ten variables that measured the respondent's ability to convey her opinions and interact with others. These values were also coded to be positive or progressive and summed across the items. Cronbach's alpha for this index was 0.72 , an acceptable value.

In addition to the indexes of self-esteem and social skills, self-efficacy was measured by a question that asked the respondent whether she belonged to any organized groups or societies. Group membership is an important measure of the peer connections that are available to a young person outside of the household, reflecting potential social resources that may be used in the future, in addition to the general benefits it confers of friendship and association with one's age mates.

Gender-role attitudes were measured by examining changes in the respondents' desired age of marriage. Although this issue was not addressed directly, it may provide information about the broader influences of the intervention.

A reproductive health knowledge variable was created by counting the number of correct answers given to eight questions related to the menstrual cycle, fertility, contraception, and sexually transmitted infections.

The "knowledge of safe spaces" variable is based on the response to a question asking whether there is "a place in your community where it is safe for unmarried adolescent girls to congregate." This variable was included because one of the goals of the intervention was to identify places in the slums that are safe for girls to meet each

other and to encourage them to visit these places so that they would become more visible 
members of the community. A second question related to mobility asked whether the respondent could go alone to visit a relative. ${ }^{12}$

To measure the time spent on domestic chores, leisure, visiting friends, and performing labor market work (paid, unpaid, or vocational training), a 20-hour schedule was recorded for the previous day. If the respondent was still in school, the day recorded was the most recent school day, even if that was not the previous day. The time-use grid was divided into hour-long segments. For each segment, all activities listed by the respondent were recorded, as was the number of minutes spent on the activity.

\section{Descriptive results}

In Table 7, we provide the mean values for each of the 13 dependent variables measured at the baseline and endline surveys separately for intervention and control groups. The results are mixed. For several variables - gender-role attitudes, knowledge of safe spaces for meeting, self-esteem, social skills, group membership, reproductive health knowledge, and mean hours spent at leisure activities - the change in the value is in the expected direction, that is, the difference between the endline and baseline surveys is greater among respondents who participated in the intervention than among respondents from the control slums, and the difference is in the desired direction. For the other variables, however-desired age at marriage, ability to go alone to visit relatives, expectation to be working in ten years, hours spent performing domestic chores, hours spent visiting friends, and hours spent in labor market work - there was either: (1) some change, but not in the desired direction, (2) the same amount of change in the control and experimental sites, or (3) less change in the experimental sites than in the control sites.

Furthermore, t-tests show that only a subset of these variables represent significant differences between the intervention and control groups at endline. Comparisons of each of the outcome variables that changed in the expected direction for intervention participants and all control respondents all showed signs of significant difference (as shown in Table 7). When the intervention participants were compared with the subsample of matched control respondents, however, only social skills, group membership, knowledge of safe spaces, reproductive health knowledge, and mean hours spent at leisure activities continued to show significant change. On balance, this descriptive analysis shows that the intervention had only a minimal effect on the attitudes and behaviors of adolescent girls.

\section{Model specification}

To assess the effect of participation in the intervention once we controlled for potentially confounding characteristics, a series of regression models was estimated for each of our outcome variables. For each model the dependent variable is the endline value of a behavioral, attitudinal, or knowledge indicator that the intervention targeted. On the right-hand side, we include the baseline measurement of that variable as well as the variable defining participation in the intervention. Because propensity score matching identifies the respondents living in the control area who were most likely to participate in the intervention had they had the opportunity, we are reasonably confident about 
significance found in the multivariate models that is associated with involvement in the intervention.

The first model estimated includes only two variables, the baseline measurement of the particular outcome plus the participation variable. The second model adds a set of potentially confounding individual characteristics at the baseline: age, whether the respondent had completed primary school, and a dummy variable for the respondents residing in the control area who attended reproductive health classes. The third model adds the set of potentially confounding household and socioeconomic variables at the baseline: whether the respondent's father had completed primary school, whether the respondent's father lived in the same household as the respondent, whether the respondent had lived her entire life in Allahabad, the number of her siblings, her caste, and the household asset quintile. This set of variables was also used to calculate the propensity score; their inclusion in the third model serves to measure any additional effect modification.

Depending on the type of outcome, the statistical model varied. With the exception of the time-use variables, for all continuous variables, indexes, and counts we used ordinary least squares (OLS). For the time-use variables, we employed a Tobit model to avoid the bias of OLS regression that potentially could occur when a substantial proportion of respondents report that they spend no time at that activity. For dichotomous variables, we used logistic regression. All models include the same set of covariates that are listed in Table 3, with the addition of a current-school-status variable for the time-use models because the ways in which adolescents occupy themselves vary considerably depending on whether or not they are enrolled in school (Ritchie et al. 2004). ${ }^{13}$

Table 8 provides a summary of the regression results for all 13 outcome variables for Model 3, which controls for all individual, household, and socioeconomic characteristics. It gives the coefficient for the variable representing participation. The full set of coefficients and the model statistics are included in Appendix Table 3. The multivariate results are fully consistent with the descriptive results shown in Table 7. Girls in the intervention are significantly more likely to have knowledge of safe spaces for meeting, be a member of a group, score higher on the social skills index, be informed about reproductive health, and spend time at leisure activities than the matched control respondents. Surprisingly, once individual, household, and socioeconomic characteristics are controlled for, intervention participants show a significant change in their desired age at marriage; however, the coefficient indicates that the desired age at marriage is decreasing, contrary to expectations. None of the other variables demonstrated that significant changes had occurred following the intervention.

\section{DISCUSSION}

Why does our analysis of the livelihoods intervention indicate such a small set of effects on the attitudes and behavior of adolescent girls in the experimental slum areas of Allahabad? A number of factors were working against our finding a substantial impact. First, as noted above, only 121 of the 635 girls in the experimental slum for whom we have both baseline and endline data participated in the intervention. That we found any 
significant effects at all is remarkable. Second, fielding a longitudinal survey in urban slum areas was more problematic than originally anticipated. Finding and successfully interviewing adolescents is a difficult task under the best of circumstances; attempting to do so in densely populated slums among a very poor population is even more demanding of both time and resources. The large difference in sample size between the baseline and the endline surveys was unexpected. Despite concerted efforts to ensure complete coverage at endline, we still missed, or could not match, a large number of adolescents who had been interviewed at baseline. Third, even when we managed to interview the same adolescents at both survey rounds, their answers to questions about aspects of their lives that logically should not have changed or should have changed in a particular direction indicated that there were reporting problems. Thus, not only was sample coverage a problem, we also experienced a degree of measurement error. Fourth, even had data collection gone smoothly, in retrospect the intervention was clearly of too short a duration and insufficiently intensive to produce a sizable effect; the girls were not involved in group meetings or vocational training for a long enough period of time to alter their attitudes or behavior significantly. In retrospect, it was naive to assume that girls exposed to an intervention for several months would be changed in any profound way, particularly as few succeeded in making money using their newly acquired skills. Fifth, the intervention had only minimal contact with the girls' parents. Yet to a large extent, these girls are not in control of their lives or their futures. Thus parents must be fully engaged in discussions of the importance of their daughters' schooling, livelihoods, and delayed marriage. ${ }^{14}$ Finally, many of the outcome variables used to evaluate the impact of the intervention were not appropriate. They were selected because of an assumption that the intervention would have a broad impact on the social context of young women's lives; instead, we found changes only for those variables that measured skills directly or for issues addressed directly by the intervention. The endline survey was adjusted to capture some domains, most notably mobility, with greater sensitivity, but these modifications in the questionnaire precluded their inclusion in this analysis. Future evaluations should, at the start, identify indicators that better reflect the subtleties of the changes that might be expected to result from the intervention.

Although our results were disappointing, the greatest changes, as noted above, were found in those outcomes that most closely reflected the content of the intervention. The increased knowledge of safe spaces for girls to meet and self-identification as a group member were direct effects of participation in the groups that met at the homes of the peer educators. Likewise, the increased social skills are a logical by-product of informal interaction within the peer groups. Finally, the most encouraging outcome is that intervention participants showed a significant increase in reproductive health knowledge, particularly because the regressions took account of those control respondents who attended the reproductive health classes that lacked the added livelihoods component. Although some of this improvement in knowledge may be related to better attendance in the experimental areas - attendance at the vocational training classes was conditional on good attendance during the reproductive health component—some unmeasured aspect of 
the livelihoods component may have encouraged the retention of reproductive health information.

A livelihoods program was not only acceptable to parents in this highly traditional slum community, but also feasible to implement. Moreover, the baseline survey clearly indicated the appropriateness of such an intervention. In Allahabad, substantial differences exist among adolescent girls and boys in terms of mobility, time-use patterns, and savings and work experience. Although a short-term program cannot alter the structure of opportunities available, it can increase awareness, social skills, knowledge of safe spaces for meeting, and group identification. In order to reduce deeply entrenched gender disparities and enhance girls' ability to have a greater voice in decisionmaking about their own lives, however, future interventions should involve many more contact hours than did the experimental project described here. They should also devote greater effort to developing group cohesion and to improving communication, negotiation, and decisionmaking skills. Finally, substantially greater resources must be provided for data collection so that the program can be properly evaluated. In light of the difficulties in identifying and following poor urban adolescents, future evaluations of interventions with people of this age group would be well advised to implement more frequent contact during the course of the project. 


\section{NOTES}

${ }^{1}$ This term was coined by Amartya Sen (1997).

${ }^{2}$ If the positive association between work and age at marriage were simply an artifact of the lengthier exposure to the "risk" of employment among those who delayed marriage, one would not expect a gradient in age of marriage by type of occupation (United Nations 1987).

${ }^{3}$ The slum areas were smaller in the control ward.

${ }^{4}$ The reproductive health sessions used a story book in the form of a flip chart to relate the experiences of Paro, a 12-year-old girl, as she learns about her reproductive health.

${ }^{5}$ An 18-year-old account holder commented about her experiences with the post office: "When I go to the post office, the staff gets angry and says come later. The other day when I had gone to the post office I wanted to deposit Rs. 300. I thought I should deposit it, or else it would be spent. They said that I could not deposit it and that I should come after a day or two. They said it was a holiday." Another account holder complained about a post office worker: "He is not a good man. He held my hand when I gave him the money. I was furious, but I didn't tell this to anyone."

${ }^{6}$ Because of the large number of houses that apparently had been abandoned, the datacollection teams returned to the slum areas eight months after the baseline survey to verify the listing data. The results from the locked-house validation study were used to determine a final response rate for the study.

${ }^{7}$ Unfortunately, information for the baseline survey is available only for those households that contained an eligible adolescent, so that the coverage in the baseline and endline surveys cannot be compared with precision.

${ }^{8}$ The remaining analyses are restricted to girls because they are the group targeted by the intervention.

${ }^{9}$ Some of those interviewed at the baseline that we have categorized as not "identified" at the endline may in fact have been interviewed but not matched to their baseline data. The background characteristics and the names reported and used to identify and match respondents may have been different across the two rounds.

${ }^{10}$ The propensity score is calculated such that

$$
\mathrm{p}(\mathrm{X}) \equiv \operatorname{Pr}\{\mathrm{D}=1 \mid \mathrm{X}\}=\mathrm{E}\{\mathrm{D} \mid \mathrm{X}\}
$$

where $\mathrm{D}=\{0,1\}$ is the indicator of exposure to the intervention, and $\mathrm{X}$ is a multidimensional vector of the baseline characteristics listed in Table 5.

${ }^{11}$ We have not included a measure of savings behavior as an outcome variable for two reasons: (1) as noted above, many of the girls found opening a savings account difficult because of the obstructionist actions of the post office staff, and (2) the questions about savings were ambiguous. Instead of asking whether the respondent had opened a savings account, respondents were asked whether they had saved, and then were asked about a savings account. In the endline survey, girls who had opened accounts but had not deposited money since opening the account interpreted the first question as asking about an active account. They then responded that they had not saved, and were not asked the second question.

${ }^{12}$ This question was part of a larger set of questions related to mobility. At baseline, the respondent was asked whether she needed permission to visit various locations. Only if 
permission was necessary was she asked whether she was allowed to go alone to the same locations. If she did not need permission, she was not asked the subsequent questions about going to these places by herself. More than 95 percent of respondents reported that they needed permission to visit relatives; thus virtually all respondents were asked the question about visiting relatives alone.

${ }^{13}$ Although current school enrollment is associated with less time spent on domestic and income-generating work, this variable is potentially endogenous because young people with heavier work burdens may drop out of school. This variable is included in the current analysis in order to control for the large difference in time-use patterns observed between girls enrolled in school and those not enrolled.

${ }^{14}$ Moreover, girls accepted parental decisions about marriage, even when those decisions did not reflect their own preferences. One intervention participant said: "Grandpa had liked the boy, finalized everything, and only then told us. This is how marriage decisions happen here." Another participant whose marriage was settled after the intervention had ended recounted seeing her future husband for the first time at her wedding: "I did not see the boy; how could I tell whether I liked him? Yes, surely I was unhappy with this. No, I did not tell anyone what I felt." 


\section{REFERENCES}

Amin, Sajeda, Ian Diamond, Ruchira T. Naved, and Margaret Newby. 1998. "Transition to adulthood of female garment-factory workers in Bangladesh." Studies in Family Planning 29(2): 185-200.

Bruce, Judith. 2002. "Thoughts on livelihoods as a process of adolescent development." Presentation made to UNICEF. New York, 8 November 2002.

Centre for Development and Population Activities (CEDPA). 2001. Adolescent Girls in India Choose a Better Future: An Impact Assessment. Washington, DC: CEDPA. http://www.cedpa.org/publications/pdf/blp_report.pdf.

Centre for Operations Research and Training (CORT). 2000. "Action for slum dwellers' reproductive health, Allahabad (ASHRA).” Baseline survey report. Vadodara, India: CORT.

D’Agostino, Jr., Ralph B. 1998. "Propensity score methods for bias reduction in the comparison of a treatment to a non-randomized control group." Statistics in Medicine 17(19): 2265-2281.

Dixon, Ruth B. 1978. Rural Women at Work: Strategies for Development in South Asia. Baltimore: Johns Hopkins University Press.

International Institute for Population Sciences (IIPS) and ORC Macro. 2000. National Family Health Survey (NFHS-2), 1998-99. Mumbai, India: IIPS and ORC Macro.

Kantor, Paula and Padmaja Nair. 2003. "Risks and responses among the urban poor in India.” Journal of International Development 15(8): 957-967.

Liebl, Maureen and Tirthankar Roy. 2003. "Handmade in India: Preliminary analysis of crafts producers and crafts production." Economic and Political Weekly 38(51-52): 53665376.

Mensch, Barbara S., Judith Bruce, and Margaret E. Greene. 1998. The Uncharted Passage: Girls' Adolescence in the Developing World. New York: Population Council.

Population Council and UNICEF. 2003. The Role of Social Support and Economic Skill Building Programs in Mitigating Adolescents' Vulnerabilities: Perspectives and UNICEF's Experience to Date. New York: Population Council and UNICEF.

Quisumbing, Agnes R. and Kelly Hallman. 2003. "Marriage in Transition: Evidence on Age, Education, and Assets from Six Developing Countries." Policy Research Division Working Paper no. 183. New York: Population Council.

$<$ http://www.popcouncil.org/pdfs/wp/183.pdf $>$. 
Ritchie, Amanda, Cynthia B. Lloyd, and Monica Grant. 2004. "Gender Differences in Time Use among Adolescents in Developing Countries: Implications of Rising School Enrollment Rates." Policy Research Division Working Paper no. 193. New York: Population Council..

Rosenbaum, Paul R. and Donald B. Rubin. 1983. "The central role of the propensity score in observational studies for causal effects." Biometrika 70(1): 41-55.

Sebstad, Jennefer and Susheela Singh. 1998. Adolescent Livelihoods Programmes: A Preliminary Review. New Delhi: Population Council.

Sen, Amartya. 1997. "Editorial: Human capital and human capability." World Development 25(12): 1959-1961.

StataCorp. 2003. Stata Statistical Software: Release 8.0 (Volume 1, Reference A-F; Volume 4, Reference $S-Z$ ). College Station, TX: Stata Corporation.

Tantri, Anupama. 2004. University of California, San Francisco-Women's Global Health Imperative. Personal Communication.

United Nations, Department of International Economic and Social Affairs. 1987. Fertility Behaviour in the Context of Development: Evidence from the World Fertility Survey. New York: United Nations. 
Table 1 Baseline and endline survey response rates of adolescents aged 14-19, by residence and sex, Allahabad, India, 2001-03

\begin{tabular}{|c|c|c|c|c|c|c|c|}
\hline \multirow[b]{2}{*}{ Response status } & \multicolumn{3}{|c|}{ Control sites } & \multicolumn{3}{|c|}{ Experimental sites } & \multirow[t]{2}{*}{ Total } \\
\hline & Male & Female & Total & Male & Female & Total & \\
\hline \multicolumn{8}{|l|}{ Baseline } \\
\hline Number of eligible young people & 890 & 835 & 1,725 & 1,341 & 1,226 & 2,567 & 4,292 \\
\hline Number of interviewed young people & 615 & 671 & 1,286 & 901 & 1,012 & 1,913 & 3,199 \\
\hline Response rate $^{\mathrm{a}}$ & 69.1 & 80.4 & 74.6 & 67.2 & 82.5 & 74.5 & 74.5 \\
\hline \multicolumn{8}{|l|}{ Endline } \\
\hline Number of eligible young people & 1,451 & 1,407 & 2,858 & 2,259 & 2,455 & 4,714 & 7,572 \\
\hline Number of interviewed young people & 1,300 & 1,215 & 2,515 & 1,773 & 1,860 & 3,633 & 6,148 \\
\hline Response rate $^{\mathrm{a}}$ & 89.6 & 86.4 & 88.0 & 78.5 & 75.8 & 77.1 & 81.2 \\
\hline \multicolumn{8}{|l|}{ Follow-up } \\
\hline $\begin{array}{l}\text { Number of young people interviewed at } \\
\text { baseline }\end{array}$ & 615 & 671 & 1,286 & 901 & 1,012 & 1,913 & 3,199 \\
\hline $\begin{array}{l}\text { Of those young people interviewed at } \\
\text { baseline, number interviewed at } \\
\text { endline }\end{array}$ & 325 & 382 & 707 & 545 & 635 & 1,180 & 1,887 \\
\hline Follow-up rate ${ }^{b}$ & 52.8 & 56.9 & 55.0 & 60.5 & 62.7 & 61.7 & 59.0 \\
\hline
\end{tabular}

${ }^{a}$ The response rate was calculated by dividing the number of those interviewed by the number of eligible young people.

${ }^{b}$ The follow-up rate was calculated by dividing the number of those interviewed in both rounds by the number of young people interviewed in the baseline survey. 
Table 2 Duration of residence in slum area, females interviewed at endline, by baseline interview status, Allahabad, India, 2003

\begin{tabular}{|c|c|c|c|c|}
\hline Interview status at baseline & $\begin{array}{l}\text { Lived in } \\
\text { slum entire } \\
\text { life }\end{array}$ & $\begin{array}{c}\text { Moved to } \\
\text { slum more } \\
\text { than two } \\
\text { years ago }\end{array}$ & $\begin{array}{l}\text { Moved to } \\
\text { slum } \\
\text { within past } \\
\text { two years }\end{array}$ & (N) \\
\hline $\begin{array}{l}\text { Matched to baseline, } \\
\text { interviewed at baseline }\end{array}$ & 90.3 & 8.1 & 1.7 & $(1,017)$ \\
\hline $\begin{array}{l}\text { Matched to baseline, } \\
\text { not interviewed at baseline }\end{array}$ & 87.3 & 10.0 & 2.7 & $(220)$ \\
\hline $\begin{array}{l}\text { Participated in intervention, } \\
\text { not interviewed at baseline }\end{array}$ & 94.6 & 4.5 & 0.9 & (111) \\
\hline $\begin{array}{l}\text { Unmatched to baseline, } \\
\text { identified at endline }\end{array}$ & 72.8 & 16.0 & 11.2 & $(1,449)$ \\
\hline $\begin{array}{l}\text { New entry, matched } \\
\text { household at baseline } \\
\text { listing }^{\mathrm{a}}\end{array}$ & 53.8 & 16.8 & 29.4 & (119) \\
\hline $\begin{array}{l}\text { Matched to baseline, } \\
\text { indicated "not eligible" at } \\
\text { baseline }\end{array}$ & 89.9 & 8.2 & 1.9 & (159) \\
\hline Total & 80.6 & 12.2 & 7.3 & $(3,075)$ \\
\hline
\end{tabular}

Note: This table includes respondents from both the experimental and the control sites.

${ }^{a}$ Note that of the 119 females identified as new entries to matched households, most had married within the past year, and probably moved into the slum to join their new conjugal household. 
Table 3 Baseline and endline characteristics of girls aged 14-19, by residence, Allahabad, India, 2001-03

\begin{tabular}{|c|c|c|c|c|c|c|}
\hline \multirow[b]{2}{*}{ Characteristic } & \multicolumn{3}{|c|}{ Baseline values } & \multicolumn{3}{|c|}{ Endline values } \\
\hline & $\begin{array}{c}\text { Control } \\
\text { sites }\end{array}$ & $\begin{array}{c}\text { Experimental } \\
\text { sites }\end{array}$ & Total & $\begin{array}{c}\text { Control } \\
\text { sites }\end{array}$ & $\begin{array}{c}\text { Experimental } \\
\text { sites }\end{array}$ & Total \\
\hline Age (mean) & 15.9 & 16.1 & 16.0 & 17.7 & 17.7 & 17.7 \\
\hline \multicolumn{7}{|l|}{ Religion (\%) } \\
\hline Hindu & 94.5 & 75.1 & 82.8 & 96.4 & 82.9 & 88.2 \\
\hline Muslim & 2.4 & 23.0 & 14.8 & 2.6 & 15.0 & 10.1 \\
\hline Other & 3.1 & 2.0 & 2.4 & 1.0 & 2.2 & 1.7 \\
\hline \multicolumn{7}{|l|}{ Caste $(\%)$} \\
\hline Scheduled caste & 56.6 & 27.7 & 39.2 & 55.5 & 39.3 & 45.7 \\
\hline Scheduled tribe & 1.3 & 0.9 & 1.1 & 1.5 & 0.4 & 0.8 \\
\hline $\begin{array}{l}\text { Other "backward" Hindu } \\
\text { caste }\end{array}$ & 21.8 & 34.1 & 29.2 & 21.0 & 29.8 & 26.3 \\
\hline High-caste Hindu & 17.6 & 14.7 & 15.8 & 18.4 & 13.8 & 15.6 \\
\hline Other religious group & 2.7 & 22.7 & 14.7 & 3.7 & 16.8 & 11.6 \\
\hline Literate father $(\%)$ & 83.9 & 82.1 & 82.8 & 85.3 & 82.2 & 83.4 \\
\hline Literate mother $(\%)$ & 48.8 & 52.9 & 51.3 & 49.6 & 41.7 & 44.8 \\
\hline $\begin{array}{l}\text { Father completed more than } \\
\text { primary school }(\%)\end{array}$ & & 53.2 & 55.1 & 57.9 & 56.3 & 56.9 \\
\hline $\begin{array}{l}\text { Father lives in same household } \\
(\%)\end{array}$ & 79.9 & 81.7 & 81.0 & 72.9 & 73.3 & 73.2 \\
\hline Ever attended school (\%) & 85.7 & 83.0 & 84.0 & 83.3 & 80.1 & 81.4 \\
\hline Completed primary school (\%) & 63.1 & 64.4 & 63.9 & 68.1 & 64.3 & 65.8 \\
\hline Currently enrolled in school (\%) & 54.3 & 55.5 & 55.1 & 47.0 & 45.6 & 46.2 \\
\hline $\begin{array}{l}\text { Lived entire life in Allahabad } \\
(\%)\end{array}$ & 88.7 & 89.3 & 89.1 & 89.5 & 91.9 & 90.9 \\
\hline Number of siblings (mean) & 3.7 & 4.1 & 4.0 & 3.7 & 4.1 & 3.9 \\
\hline Asset quintiles (\%) & & & & & & \\
\hline Low & 22.2 & 18.5 & 19.9 & 21.6 & 20.1 & 20.7 \\
\hline Low-middle & 22.8 & 20.7 & 21.5 & 21.1 & 19.1 & 19.9 \\
\hline Middle & 19.1 & 20.2 & 19.5 & 21.1 & 19.4 & 20.1 \\
\hline High-middle & 17.8 & 20.4 & 19.4 & 18.7 & 18.7 & 18.7 \\
\hline High & 18.2 & 20.2 & 19.4 & 17.6 & 22.7 & 20.7 \\
\hline$(\mathrm{N})$ & (670) & $(1,010)$ & $(1,680)$ & $(1,215)$ & $(1,860)$ & $(3,075)$ \\
\hline
\end{tabular}


Table 4 Baseline and endline characteristics of girls aged 14-19, by interview status, Allahabad, India, 2001-03

\begin{tabular}{|c|c|c|c|c|}
\hline \multirow[b]{2}{*}{ Characteristic } & \multicolumn{2}{|c|}{ Baseline values } & \multicolumn{2}{|c|}{ Endline values } \\
\hline & $\begin{array}{l}\text { Interviewed } \\
\text { at baseline } \\
\text { only }\end{array}$ & $\begin{array}{l}\text { Interviewed } \\
\text { at baseline } \\
\text { and endline }\end{array}$ & $\begin{array}{l}\text { Interviewed } \\
\text { at endline } \\
\text { only }\end{array}$ & $\begin{array}{l}\text { Interviewed } \\
\text { at baseline } \\
\text { and endline }\end{array}$ \\
\hline Age (mean) & 16.1 & 16.0 & 17.6 & 17.8 \\
\hline \multicolumn{5}{|l|}{ Religion (\%) } \\
\hline Hindu & 78.9 & 85.4 & 89.0 & 86.7 \\
\hline Muslim & 19.2 & 11.9 & 9.2 & 11.9 \\
\hline Other & 2.0 & 2.8 & 1.9 & 1.4 \\
\hline \multicolumn{5}{|l|}{ Caste (\%) } \\
\hline Scheduled caste & 36.7 & 40.9 & 45.4 & 46.1 \\
\hline Scheduled tribe & 1.1 & 1.1 & 0.8 & 0.9 \\
\hline \multicolumn{5}{|l|}{ Other "backward" Hindu } \\
\hline caste & 26.2 & 31.1 & 27.2 & 24.5 \\
\hline High-caste Hindu & 16.9 & 15.1 & 16.4 & 13.9 \\
\hline Other religious group & 19.2 & 11.8 & 10.2 & 14.7 \\
\hline Literate father $(\%)$ & 79.9 & 84.7 & 82.4 & 85.5 \\
\hline Literate mother $(\%)$ & 46.3 & 54.5 & 43.1 & 48.4 \\
\hline \multicolumn{4}{|l|}{ Father completed more than primary } & 60.3 \\
\hline Father lives in same household (\%) & 79.2 & 82.1 & 68.6 & 82.5 \\
\hline Ever attended school (\%) & 78.4 & 87.7 & 79.1 & 85.9 \\
\hline Completed primary school (\%) & 57.8 & 67.9 & 62.5 & 72.5 \\
\hline Currently enrolled in school (\%) & 48.9 & 59.1 & 43.4 & 51.6 \\
\hline Lived entire life in Allahabad (\%) & 89.3 & 89.0 & 89.0 & 94.8 \\
\hline Number of siblings (mean) & 3.8 & 4.0 & 3.9 & 4.1 \\
\hline \multicolumn{5}{|l|}{ Asset quintiles (\%) } \\
\hline Low & 23.5 & 18.0 & 23.0 & 16.0 \\
\hline Low-middle & 22.9 & 20.7 & 21.0 & 17.6 \\
\hline Middle & 17.8 & 20.8 & 19.4 & 21.5 \\
\hline High-middle & 18.8 & 19.7 & 18.5 & 19.2 \\
\hline High & 17.1 & 20.7 & 18.2 & 25.7 \\
\hline$(\mathrm{N})$ & $(663)$ & $(1,017)$ & $(2,058)$ & $(1,017)$ \\
\hline
\end{tabular}


Table 5 Baseline characteristics, before and after propensity score matching, Allahabad, India, 2001-03

Characteristic Intervention Control (all) Control (matched)

Father lives in same household (\%)

89.3

$79.8 *$

87.2

Caste (\%)

Scheduled caste

45.9

Scheduled tribe

1.6

$59.3^{* *}$

49.6

Other "backward" Hindu caste

40.2

High-caste Hindu

9.8

1.3

0.9

Other religious group

2.5

$20.7 * * *$

39.3

17.1

6.8

1.6

3.4

Father completed more than primary school (\%)

39.3

$60.1 * * *$

38.5

Lived entire life in Allahabad (\%)

92.6

87.4

97.4

Number of siblings (mean)

4.5

$3.7 * * *$

4.5

Asset quintiles (\%)

Low

19.7

17.6

29.1

Low-middle

26.5

21.8

28.2

Middle

27.4

20.4

22.2

High-middle

17.1

19.6

13.7

High

9.4

$20.7^{* *}$

6.8

(N)

(122)

(381)

(117)

Note: Significance is based on the t-test of means comparing the intervention to each control sample.

$* \mathrm{p} \leq 0.05 ; * * \mathrm{p} \leq 0.01 ; * * * \mathrm{p} \leq 0.001$. 
Table 6 Description of dependent variables, Allahabad, India, 2001-03

\begin{tabular}{|c|c|c|c|c|c|}
\hline Variable & $\begin{array}{l}\text { Number of } \\
\text { components }\end{array}$ & $\begin{array}{l}\text { Type of } \\
\text { variable }\end{array}$ & $\begin{array}{l}\text { Possible } \\
\text { range }\end{array}$ & $\begin{array}{l}\text { Baseline } \\
\text { range }\end{array}$ & $\begin{array}{l}\text { Endline } \\
\text { range }\end{array}$ \\
\hline \multicolumn{6}{|l|}{ Gender roles } \\
\hline Gender role index & 8 & Index & $0-16$ & $2-16$ & $2-16$ \\
\hline Desired age at marriage & 1 & Continuous & n.a. & $12-29$ & $18-25$ \\
\hline \multicolumn{6}{|l|}{ Self-efficacy } \\
\hline Self-esteem index & 6 & Index & $0-12$ & $3-12$ & $0-12$ \\
\hline Social skills index & 10 & Index & $0-20$ & $0-17$ & $2-20$ \\
\hline Group membership & 1 & Dichotomous & $0-1$ & $0-1$ & $0-1$ \\
\hline \multicolumn{6}{|l|}{ Mobility } \\
\hline $\begin{array}{l}\text { Knowledge of safe spaces for } \\
\text { girls }\end{array}$ & 1 & Dichotomous & $0-1$ & $0-1$ & $0-1$ \\
\hline Can go alone to visit relatives & 1 & Dichotomous & $0-1$ & $0-1$ & $0-1$ \\
\hline Reproductive health knowledge & 8 & Count & $0-8$ & $0-7$ & $1-8$ \\
\hline \multicolumn{2}{|l|}{ Work expectations and time use } & Dichotomous & $0-1$ & $0-1$ & $0-1$ \\
\hline $\begin{array}{l}\text { Hours spent visiting friends } \\
\text { (inside and outside household) }\end{array}$ & 2 & Continuous & $0-20$ & $0-8.83$ & $0-7$ \\
\hline $\begin{array}{l}\text { Hours spent performing } \\
\text { domestic chores }\end{array}$ & 3 & Continuous & $0-20$ & $0-14$ & $0-13.67$ \\
\hline $\begin{array}{l}\text { Hours spent in labor market work } \\
\text { (paid, unpaid, vocational } \\
\text { training) }\end{array}$ & 3 & Continuous & $0-20$ & $0-12$ & $0-13$ \\
\hline $\begin{array}{l}\text { Hours spent at leisure } \\
\text { activities }\end{array}$ & 7 & Continuous & $0-20$ & $0-10.17$ & $0-10$ \\
\hline
\end{tabular}


Table 7 Dependent variables at baseline and endline surveys, by participation in the livelihoods intervention, Allahabad, India, 2001-03

\begin{tabular}{|c|c|c|c|c|c|c|}
\hline \multirow[b]{2}{*}{ Dependent variable } & \multicolumn{3}{|c|}{ Baseline } & \multicolumn{3}{|c|}{ Endline } \\
\hline & Intervention & $\begin{array}{c}\text { Control } \\
\text { (all) }\end{array}$ & $\begin{array}{c}\text { Control } \\
\text { (matched) }\end{array}$ & Intervention & $\begin{array}{c}\text { Control } \\
\text { (all) }\end{array}$ & $\begin{array}{c}\text { Control } \\
\text { (matched) }\end{array}$ \\
\hline \multicolumn{7}{|l|}{ Gender roles } \\
\hline $\begin{array}{l}\text { Gender role index } \\
\text { (mean) }\end{array}$ & 13.0 & 13.5 & 13.0 & 14.1 & $13.2 *$ & 13.4 \\
\hline $\begin{array}{l}\text { Desired age at marriage } \\
\text { (mean) }\end{array}$ & 19.3 & 19.4 & 19.1 & 19.0 & $19.4^{*}$ & 19.2 \\
\hline \multicolumn{7}{|l|}{ Self-efficacy } \\
\hline $\begin{array}{l}\text { Self-esteem index } \\
\quad \text { (mean) }\end{array}$ & 10.6 & 10.6 & 10.5 & 10.7 & $9.9^{*}$ & 10.2 \\
\hline $\begin{array}{l}\text { Social skills index } \\
\text { (mean) }\end{array}$ & 9.6 & 9.4 & 9.2 & 12.0 & $11.1 * *$ & $11.0 *$ \\
\hline Group membership (\%) & 1.7 & 2.7 & 2.6 & 15.6 & $2.6 * * *$ & $5.1 * *$ \\
\hline \multicolumn{7}{|l|}{ Mobility } \\
\hline $\begin{array}{l}\text { Knowledge of safe } \\
\text { spaces for girls }(\%)\end{array}$ & 16.8 & $8.4^{*}$ & $4.6^{* *}$ & 83.2 & $27.9 * * *$ & $33.7 * * *$ \\
\hline $\begin{array}{l}\text { Can go alone to visit } \\
\text { relatives }(\%)\end{array}$ & 20.7 & 25.0 & 19.8 & 23.8 & $37.0 * *$ & 34.2 \\
\hline $\begin{array}{l}\text { Reproductive health } \\
\text { knowledge (mean) }\end{array}$ & 4.0 & 4.3 & 3.9 & 6.7 & $5.8^{* * *}$ & $5.7 * * *$ \\
\hline $\begin{array}{l}\text { Work expectations and } \\
\text { time use } \\
\text { Expect to be working in } \\
\text { ten years }(\%)\end{array}$ & 73.7 & 71.8 & 67.3 & 61.7 & 60.5 & 56.5 \\
\hline $\begin{array}{l}\text { Hours spent visiting } \\
\text { friends (mean) }\end{array}$ & 0.5 & $0.2 * *$ & 0.3 & 0.4 & 0.5 & 0.6 \\
\hline $\begin{array}{l}\text { Hours spent performing } \\
\text { domestic chores } \\
\text { (mean) }\end{array}$ & 5.0 & $4.0 * * *$ & 4.5 & 5.2 & $4.3 * * *$ & 4.7 \\
\hline $\begin{array}{l}\text { Hours spent in labor } \\
\text { market work (mean) }\end{array}$ & 0.3 & 0.2 & 0.4 & 0.1 & 0.2 & $0.2^{*}$ \\
\hline $\begin{array}{l}\text { Hours spent at leisure } \\
\text { activities (mean) }\end{array}$ & 3.8 & 3.5 & 3.9 & 4.4 & $3.8^{*}$ & $3.7^{*}$ \\
\hline$(\mathrm{N})$ & $(122)$ & (381) & (117) & (122) & (381) & (117) \\
\hline
\end{tabular}

Note: Significance is based on the t-test of means comparing the intervention to each control sample.

$* \mathrm{p} \leq 0.05 ; * * \mathrm{p} \leq 0.01 ; * * * \mathrm{p} \leq 0.001$. 
Table 8 Summary of Model 3 regression results: Effect of participation in the livelihoods intervention, Allahabad, India, 2001-03

\begin{tabular}{|c|c|c|c|c|c|}
\hline Variable & Coefficient & $\begin{array}{c}\begin{array}{c}\text { Standard } \\
\text { error }\end{array} \\
\end{array}$ & $\begin{array}{l}\text { Odds } \\
\text { ratio }\end{array}$ & P-value & Regression type \\
\hline Gender role index & 0.686 & 0.492 & & 0.164 & Linear regression \\
\hline Desired age at marriage & -0.485 & 0.201 & & 0.017 & Linear regression \\
\hline $\begin{array}{l}\text { Can go alone to visit } \\
\text { relatives }\end{array}$ & -0.615 & 0.342 & 0.541 & 0.072 & $\begin{array}{l}\text { Logistic } \\
\text { regression }\end{array}$ \\
\hline $\begin{array}{l}\text { Knowledge of safe spaces } \\
\text { for girls }\end{array}$ & 2.495 & 0.405 & 12.126 & 0.000 & $\begin{array}{l}\text { Logistic } \\
\text { regression }\end{array}$ \\
\hline Self-esteem index & 0.561 & 0.409 & & 0.171 & Linear regression \\
\hline Social skills index & 0.988 & 0.401 & & 0.015 & Linear regression \\
\hline Group membership & 1.621 & 0.589 & 5.057 & 0.006 & $\begin{array}{l}\text { Logistic } \\
\text { regression }\end{array}$ \\
\hline $\begin{array}{l}\text { Reproductive health } \\
\text { knowledge }\end{array}$ & 0.952 & 0.153 & & 0.000 & Linear regression \\
\hline $\begin{array}{l}\text { Expect to be working in } \\
\text { ten years }\end{array}$ & 0.156 & 0.319 & 1.169 & 0.625 & $\begin{array}{l}\text { Logistic } \\
\text { regression }\end{array}$ \\
\hline $\begin{array}{l}\text { Hours spent visiting } \\
\text { friends (inside and } \\
\text { outside household) }\end{array}$ & -0.400 & 0.319 & & 0.212 & $\begin{array}{l}\text { Tobit regression, } \\
\text { left censored }\end{array}$ \\
\hline $\begin{array}{l}\text { Hours spent performing } \\
\text { domestic chores }\end{array}$ & 0.422 & 0.284 & & 0.14 & $\begin{array}{l}\text { Tobit regression, } \\
\text { left censored }\end{array}$ \\
\hline $\begin{array}{l}\text { Hours spent in labor } \\
\text { market work (paid, } \\
\text { unpaid, vocational } \\
\text { training) }\end{array}$ & -0.493 & 0.301 & & 0.103 & $\begin{array}{l}\text { Tobit regression, } \\
\text { left censored }\end{array}$ \\
\hline $\begin{array}{l}\text { Hours spent at leisure } \\
\text { activities }\end{array}$ & 0.722 & 0.231 & & 0.002 & $\begin{array}{l}\text { Tobit regression, } \\
\text { left censored }\end{array}$ \\
\hline
\end{tabular}


Appendix Table 1 Baseline and endline characteristics of girls aged 14-19, by interview status and residence, Allahabad, India, 2001-03

\begin{tabular}{|c|c|c|c|c|c|c|c|c|}
\hline \multirow[b]{3}{*}{ Characteristic } & \multicolumn{4}{|c|}{ Baseline values } & \multicolumn{4}{|c|}{ Endline values } \\
\hline & \multicolumn{2}{|c|}{$\begin{array}{l}\text { Interviewed at } \\
\text { baseline only }\end{array}$} & \multicolumn{2}{|c|}{$\begin{array}{c}\text { Interviewed at } \\
\text { baseline and endline }\end{array}$} & \multicolumn{2}{|c|}{$\begin{array}{l}\text { Interviewed at } \\
\text { endline only }\end{array}$} & \multicolumn{2}{|c|}{$\begin{array}{c}\text { Interviewed at } \\
\text { baseline and endline }\end{array}$} \\
\hline & $\begin{array}{c}\text { Control } \\
\text { site }\end{array}$ & $\begin{array}{c}\text { Experimental } \\
\text { site }\end{array}$ & $\begin{array}{c}\text { Control } \\
\text { site }\end{array}$ & $\begin{array}{c}\text { Experimental } \\
\text { site }\end{array}$ & $\begin{array}{c}\text { Control } \\
\text { site } \\
\end{array}$ & $\begin{array}{l}\text { Experimental } \\
\text { site } \\
\end{array}$ & $\begin{array}{c}\text { Control } \\
\text { site } \\
\end{array}$ & $\begin{array}{c}\text { Experimental } \\
\text { site } \\
\end{array}$ \\
\hline Age (mean) & 16.0 & 16.1 & 15.9 & 16.0 & 17.7 & 17.6 & 17.8 & 17.8 \\
\hline \multicolumn{9}{|l|}{ Religion (\%) } \\
\hline Hindu & 93.8 & 67.5 & 95.0 & 79.5 & 95.8 & 84.3 & 97.6 & 80.2 \\
\hline Muslim & 3.1 & 31.5 & 1.8 & 18.0 & 3.0 & 13.4 & 1.8 & 18.0 \\
\hline Other & 3.1 & 1.1 & 3.1 & 2.5 & 1.2 & 2.3 & 0.5 & 1.9 \\
\hline \multicolumn{9}{|l|}{ Caste $(\%)$} \\
\hline Scheduled caste & 52.8 & 24.3 & 59.4 & 29.8 & 54.0 & 39.6 & 58.6 & 38.6 \\
\hline Scheduled tribe & 1.4 & 0.8 & 1.3 & 0.9 & 1.4 & 0.3 & 1.6 & 0.5 \\
\hline Other "backward" Hindu caste & 23.3 & 28.5 & 20.7 & 37.3 & 21.4 & 31.2 & 20.2 & 27.1 \\
\hline High-caste Hindu & 18.4 & 15.7 & 17.0 & 14.0 & 19.2 & 14.5 & 16.5 & 12.3 \\
\hline Other religious group & 4.2 & 30.7 & 1.6 & 18.0 & 4.0 & 14.4 & 3.1 & 21.6 \\
\hline Literate father $(\%)$ & 81.9 & 78.3 & 85.3 & 84.4 & 85.1 & 80.5 & 85.6 & 85.4 \\
\hline Literate mother $(\%)$ & 46.5 & 46.1 & 50.5 & 57.0 & 50.2 & 38.2 & 48.2 & 48.5 \\
\hline Completed primary school (\%) & 58.0 & 57.6 & 67.0 & 68.3 & 66.0 & 60.1 & 72.5 & 72.4 \\
\hline Currently enrolled in school (\%) & 49.3 & 48.5 & 58.1 & 59.7 & 45.0 & 42.4 & 51.3 & 51.8 \\
\hline Lived entire life in Allahabad (\%) & 90.3 & 88.5 & 87.4 & 89.8 & 87.5 & 90.0 & 93.7 & 95.4 \\
\hline Number of siblings (mean) & 3.6 & 4.0 & 3.7 & 4.2 & 3.7 & 4.0 & 3.8 & 4.2 \\
\hline$(\mathrm{N})$ & $(288)$ & $(375)$ & $(382)$ & $(635)$ & $(833)$ & $(1,225)$ & $(382)$ & $(635)$ \\
\hline
\end{tabular}


Appendix Table 2 Dependent variables: List of components and questions

Gender roles (agree/disagree):

"A woman should be allowed to work for cash."

"If the wife has a job outside the home then the husband should help her with the children and household chores."

"Boys should be asked to spend time on household duties."

"Girls should be allowed to decide when they want to marry."

"Women are generally inferior to men."

"If a girl has not gone to school, the best thing for her is an early marriage."

"If a woman does not have a son, she should keep trying even if she is satisfied with the number of daughters she has."

"Girls are as good in business as boys."

Desired age at marriage (asked only of unmarried respondents):

"How old would you like to be when you get married?"

Self-efficacy (agree/disagree):

"You feel like you have a number of good attributes."

"You feel as important to your family as other members."

"You feel capable of doing as many things as other people."

"You feel you are important to your friends."

"When there is a family discussion, your parent(s) respect your opinion."

"Your parent(s) or in-law(s) feel that you have many good qualities."

Social skills (agree/disagree):

"Do you find it difficult to talk to elders in your family?"

"Do you find it difficult to talk in front of a group?"

"Do you think you can express your ideas to others?"

"Do you think you can convince people of what you believe in?"

"Do you find it easy to make new friends?"

(not good/very good):

"How good are you at solving your daily problems?"

"How good are you at making yourself understood to other people?"

"How good are you at listening to other people?"

"How good are you at asserting your opinions about issues?"

"How good are you at initiating activities in a group?"

\section{Group membership:}

"Do you belong to any organized groups or societies - popular organizations, labor unions, farmer's unions, social clubs, athletic clubs, or any other organized groups?"

\section{Mobility:}

"Can you go alone to visit relatives?"

\section{Knowledge of safe spaces:}

"Is there a place in your community where it is safe for unmarried adolescent girls to congregate?" 


\section{Reproductive health knowledge:}

"When during a woman's monthly menstrual cycle is pregnancy most likely to occur?"

"How does a girl get pregnant?"

"How long does a fetus remain in a mother's womb?"

"Do you know the names of any diseases that can be transmitted via sexual relations?"

"Can a person always tell if another person has a sexually transmitted infection, or is it sometimes hard or impossible to tell?"

"Can a married woman contract AIDS if her only sexual partner is her husband?"

"Could you tell me what methods [of family planning] you have heard about?"

"Do any contraceptive methods protect against HIV/AIDS or STIs?"

\section{Expect to work in ten years:}

"I would like to know your thoughts about your future employment. Ten years from now, do you expect to be working for pay?"

\section{Hours visiting friends:}

"How many hours do you spend visiting with friends inside the household?"

"How many hours do you spend visiting with friends outside the household?"

\section{Hours spent performing domestic chores:}

"How many hours do you spend on household chores inside the house (for example, dishwashing, cleaning, cooking, mending)?"

"How many hours do you spend on household chores outside the house (for example, raising food or livestock for family use, fetching water)?"

"How many hours do you spend on care of children, the sick, and the elderly?"

\section{Hours spent in labor market work:}

"How many hours do you spend on paid work?"

"How many hours do you spend on unpaid work (not including chores and raising family food)?"

"How many hours do you spend on vocational counseling or training?"

\section{Hours spent at leisure activities:}

"How many hours do you spend taking rest/relaxation/nap?"

"How many hours do you spend visiting the adolescent resource center?"

"How many hours do you spend on games or sports?"

"How many hours do you spend watching television or movies?"

"How many hours do you spend playing or listening to music?"

"How many hours do you spend reading magazines or stories?"

"How many hours do you spend on other recreation?" 
Appendix Table 3 Regression coefficients

\begin{tabular}{|c|c|c|c|c|c|c|c|c|c|c|c|c|}
\hline \multirow[b]{2}{*}{ Variable } & \multicolumn{3}{|c|}{$\begin{array}{c}\text { Gender-role index } \\
\text { Model number }\end{array}$} & \multicolumn{3}{|c|}{$\begin{array}{c}\text { Desired age at marriage } \\
\text { Model number }\end{array}$} & \multicolumn{3}{|c|}{$\begin{array}{l}\text { Self-esteem index } \\
\text { Model number }\end{array}$} & \multicolumn{3}{|c|}{$\begin{array}{l}\text { Social skills index } \\
\text { Model number }\end{array}$} \\
\hline & 1 & 2 & 3 & 1 & 2 & 3 & 1 & 2 & 3 & 1 & 2 & 3 \\
\hline Intervention & 0.62 & 0.72 & 0.64 & -0.30 & -0.37 & $-0.45^{*}$ & 0.66 & 0.66 & 0.58 & $0.87 *$ & $1.01^{*}$ & $0.99 *$ \\
\hline Baseline value & -0.02 & -0.04 & -0.07 & $0.27 * * *$ & $0.26^{* * *}$ & $0.23 * * *$ & $0.28 * * *$ & $0.28 * *$ & $0.24 *$ & -0.01 & -0.02 & -0.03 \\
\hline $\begin{array}{l}\text { Attended RH meeting in } \\
\text { control area }\end{array}$ & & 0.84 & 0.08 & & -0.40 & -0.52 & & 0.03 & -0.46 & & 1.37 & 1.40 \\
\hline Age & & 0.01 & -0.10 & & -0.01 & -0.01 & & 0.01 & -0.06 & & -0.01 & -0.02 \\
\hline Completed primary school & & 0.50 & 0.29 & & $0.44 *$ & 0.23 & & 0.04 & -0.38 & & $1.63 * * *$ & $1.33 * *$ \\
\hline $\begin{array}{l}\text { Currently in school } \\
\text { Father lives in household }\end{array}$ & & & $\begin{array}{l}\text { n.a. } \\
-1.68^{*}\end{array}$ & & & $\begin{array}{l}\text { n.a. } \\
-0.01\end{array}$ & & & $\begin{array}{l}\text { n.a. } \\
-1.34 *\end{array}$ & & & $\begin{array}{l}\text { n.a. } \\
1.04\end{array}$ \\
\hline $\begin{array}{l}\text { Father completed more } \\
\text { than primary school }\end{array}$ & & & $1.08 *$ & & & 0.05 & & & 0.54 & & & -0.06 \\
\hline $\begin{array}{l}\text { Lived entire life in } \\
\text { Allahabad }\end{array}$ & & & -0.03 & & & -0.64 & & & -1.44 & & & 0.46 \\
\hline Number of siblings & & & 0.23 & & & 0.04 & & & 0.18 & & & -0.11 \\
\hline $\begin{array}{l}\text { Scheduled tribe (vs. } \\
\text { scheduled caste) }\end{array}$ & & & 0.20 & & & 0.13 & & & -0.08 & & & -1.03 \\
\hline $\begin{array}{l}\text { Other "backward" Hindu } \\
\text { caste (vs. scheduled } \\
\text { caste) }\end{array}$ & & & -0.22 & & & -0.05 & & & -0.09 & & & -0.09 \\
\hline $\begin{array}{l}\text { High-caste Hindu (vs. } \\
\text { scheduled caste) }\end{array}$ & & & 0.11 & & & 0.35 & & & -0.63 & & & -0.45 \\
\hline $\begin{array}{l}\text { Other religious group (vs. } \\
\text { scheduled caste) }\end{array}$ & & & 0.77 & & & -0.24 & & & 0.43 & & & 1.79 \\
\hline SES low-middle (vs. low) & & & -0.70 & & & -0.05 & & & -0.07 & & & 0.65 \\
\hline SES middle (vs. low) & & & 0.99 & & & 0.45 & & & $1.42 *$ & & & 1.06 \\
\hline SES high-middle (vs. low) & & & 0.42 & & & 0.58 & & & 0.79 & & & 0.76 \\
\hline SES high (vs. low) & & & -0.35 & & & 0.62 & & & 1.43 & & & 1.54 \\
\hline $\begin{array}{l}\text { Constant } \\
\text { (N) }\end{array}$ & $\begin{array}{l}13.73 * * * \\
(231)\end{array}$ & $\begin{array}{l}13.39 * * * \\
(231)\end{array}$ & $\begin{array}{l}15.77 * * * \\
(226)\end{array}$ & $\begin{array}{l}14.05 * * * \\
(215)\end{array}$ & $\begin{array}{l}14.33 * * * \\
(215)\end{array}$ & $\begin{array}{l}15.18 * * * \\
(212)\end{array}$ & $\begin{array}{c}7.25 * * * \\
(233)\end{array}$ & $\begin{array}{c}7.10 * * * \\
(233)\end{array}$ & $\begin{array}{l}10.10^{* * *} \\
(228)\end{array}$ & $\begin{array}{l}11.23 * * * \\
(223)\end{array}$ & $\begin{array}{l}10.38 * * * \\
(223)\end{array}$ & $\begin{array}{c}9.34 * * * \\
(219)\end{array}$ \\
\hline F-statistic & 0.96 & 0.81 & 1.33 & 14.72 & 7.22 & 2.73 & 5.85 & 2.31 & 1.65 & 2.45 & 5.58 & 2.23 \\
\hline $\begin{array}{l}\text { R-squared } \\
\text { Log likelihood }\end{array}$ & -0.0004 & -0.0043 & 0.0242 & 0.1137 & 0.1269 & 0.1221 & 0.0401 & 0.0275 & 0.0462 & 0.0129 & 0.0934 & 0.0872 \\
\hline
\end{tabular}

n..$=$ not available. $\mathrm{RH}=$ reproductive health.

$* \mathrm{p} \leq 0.05 ; * * \mathrm{p} \leq 0.01 ; * * * \mathrm{p} \leq 0.001$.

${ }^{\mathrm{a}}=$ Adjusted R-squared used for linear regressions; pseudo R-squared used for logit regressions. Please see Table 8 for regression type.

$\mathrm{b}=$ Variable predicts failure perfectly. 
Appendix Table 3 Regression coefficients (continued)

\begin{tabular}{|c|c|c|c|c|c|c|c|c|c|c|c|c|}
\hline \multirow[t]{2}{*}{ Variable } & \multicolumn{3}{|c|}{$\begin{array}{l}\text { Group membership } \\
\text { Model number }\end{array}$} & \multicolumn{3}{|c|}{$\begin{array}{c}\text { Knowledge of safe spaces } \\
\text { Model number }\end{array}$} & \multicolumn{3}{|c|}{$\begin{array}{c}\text { Can go alone to visit relatives } \\
\text { Model number } \\
\end{array}$} & \multicolumn{3}{|c|}{$\begin{array}{c}\text { Reproductive health knowledge } \\
\text { index } \\
\text { Model number }\end{array}$} \\
\hline & 1 & 2 & 3 & 1 & 2 & 3 & 1 & 2 & 3 & 1 & 2 & 3 \\
\hline Intervention & $1.24 *$ & $1.46^{* *}$ & $1.62 * *$ & $2.31 * * *$ & $2.48 * * *$ & $2.50 * * *$ & $-0.64 *$ & -0.61 & -0.66 & $0.94 * * *$ & $0.93 * * *$ & $0.97 * * *$ \\
\hline Baseline value & $\mathrm{b}$ & $\mathrm{b}$ & $\mathrm{b}$ & 0.10 & 0.08 & 0.11 & 0.50 & 0.50 & 0.58 & 0.08 & 0.01 & -0.01 \\
\hline $\begin{array}{l}\text { Attended RH meeting in } \\
\text { control area }\end{array}$ & & 0.87 & 0.90 & & 0.95 & 0.78 & & 0.61 & 0.56 & & 0.14 & 0.10 \\
\hline Age & & -0.05 & -0.08 & & 0.04 & 0.00 & & 0.15 & 0.14 & & 0.04 & 0.02 \\
\hline Completed primary school & & $1.60 * *$ & $1.29 *$ & & 0.42 & 0.57 & & $0.67 *$ & $0.72 *$ & & $0.51 * * *$ & $0.42 *$ \\
\hline $\begin{array}{l}\text { Currently in school } \\
\text { Father lives in household }\end{array}$ & & & $\begin{array}{l}\text { n.a. } \\
0.06\end{array}$ & & & $\begin{array}{l}\text { n.a. } \\
-0.42\end{array}$ & & & $\begin{array}{l}\text { n.a. } \\
0.21\end{array}$ & & & $\begin{array}{l}\text { n.a. } \\
0.11\end{array}$ \\
\hline $\begin{array}{l}\text { Father completed more } \\
\text { than primary school }\end{array}$ & & & 0.27 & & & -0.55 & & & -0.40 & & & 0.10 \\
\hline $\begin{array}{l}\text { Lived entire life in } \\
\text { Allahabad }\end{array}$ & & & b & & & -0.03 & & & 0.29 & & & $0.80 *$ \\
\hline Number of siblings & & & 0.00 & & & -0.11 & & & 0.04 & & & 0.06 \\
\hline $\begin{array}{l}\text { Scheduled tribe (vs. } \\
\text { scheduled caste) }\end{array}$ & & & $\mathrm{b}$ & & & $\mathrm{b}$ & & & $\mathrm{b}$ & & & -0.43 \\
\hline $\begin{array}{l}\text { Other "backward" Hindu } \\
\text { caste (vs. scheduled } \\
\text { caste) }\end{array}$ & & & -0.13 & & & -0.60 & & & -0.20 & & & -0.13 \\
\hline $\begin{array}{l}\text { High caste Hindu (vs. } \\
\text { scheduled caste) }\end{array}$ & & & -1.91 & & & 0.92 & & & 0.55 & & & 0.27 \\
\hline $\begin{array}{l}\text { Other religious group (vs. } \\
\text { scheduled caste) }\end{array}$ & & & $\mathrm{b}$ & & & 0.13 & & & $\mathrm{~b}$ & & & 0.34 \\
\hline SES low-middle (vs. low) & & & 0.00 & & & -0.10 & & & -0.40 & & & 0.14 \\
\hline SES middle (vs. low) & & & -0.27 & & & 0.32 & & & -0.34 & & & 0.10 \\
\hline SES high-middle (vs. low) & & & -0.09 & & & 0.51 & & & -1.03 & & & 0.41 \\
\hline SES high (vs. low) & & & 1.22 & & & -0.19 & & & -0.12 & & & 0.15 \\
\hline Constant & $\begin{array}{c}-2.88 * * * \\
(230)\end{array}$ & $\begin{array}{l}-3.35 \\
(230)\end{array}$ & $\begin{array}{l}-2.76 \\
(204)\end{array}$ & $\begin{array}{c}-0.68^{* *} \\
(200)\end{array}$ & $\begin{array}{l}-1.66 \\
(200)\end{array}$ & $\begin{array}{r}-0.06 \\
(194)\end{array}$ & $\begin{array}{c}-0.72 * * * \\
(227)\end{array}$ & $\begin{array}{c}-3.57^{*} \\
(227)\end{array}$ & $\begin{array}{l}-3.46 \\
(213)\end{array}$ & $\begin{array}{l}5.41 * * * \\
(239)\end{array}$ & $\begin{array}{c}4.68 * * * \\
(239)\end{array}$ & $\begin{array}{c}3.93 * * * \\
(234)\end{array}$ \\
\hline F-statistic & & & & & & & & & & 23.02 & 12.04 & 4.47 \\
\hline R-squared ${ }^{\mathrm{a}}$ & 0.047 & 0.1156 & 0.156 & 0.2037 & 0.2226 & 0.2483 & 0.0239 & 0.0552 & 0.0781 & 0.1562 & 0.1882 & 0.202 \\
\hline Log likelihood & -75.355 & -69.928 & -64.048 & -107.18 & -104.64 & -98.833 & -132.686 & -128.434 & -120.025 & & & \\
\hline
\end{tabular}

n.a. $=$ not available. $\mathrm{RH}=$ reproductive healt

$* \mathrm{p} \leq 0.05 ; * * \mathrm{p} \leq 0.01 ; * * * \mathrm{p} \leq 0.001$.

${ }^{\mathrm{a}}=$ Adjusted R-squared used for linear regressions; pseudo R-squared used for logit regressions. Please see Table 8 for regression type.

$\mathrm{b}=$ Variable predicts failure perfectly. 
Appendix Table 3 Regression coefficients (continued)

\begin{tabular}{|c|c|c|c|c|c|c|c|c|c|}
\hline \multirow[b]{2}{*}{ Variable } & \multicolumn{3}{|c|}{$\begin{array}{c}\text { Expectation to work in ten years } \\
\text { Model number }\end{array}$} & \multicolumn{3}{|c|}{$\begin{array}{c}\text { Hours at domestic work } \\
\text { Model number }\end{array}$} & \multicolumn{3}{|c|}{$\begin{array}{c}\text { Hours at labor market work } \\
\text { Model number }\end{array}$} \\
\hline & 1 & 2 & 3 & 1 & 2 & 3 & 1 & 2 & 3 \\
\hline Intervention & 0.21 & 0.17 & 0.16 & 0.35 & 0.42 & 0.42 & $-0.59^{*}$ & -0.55 & -0.49 \\
\hline Baseline value & 0.61 & 0.55 & 0.57 & $0.30 * * *$ & 0.09 & 0.09 & 0.14 & 0.13 & 0.12 \\
\hline $\begin{array}{l}\text { Attended RH meeting in } \\
\text { control area }\end{array}$ & & -0.05 & 0.00 & & 0.16 & 0.19 & & 0.36 & 0.56 \\
\hline Age & & -0.08 & -0.08 & & 0.04 & 0.04 & & 0.03 & -0.07 \\
\hline Completed primary school & & $0.69 *$ & 0.58 & & -0.03 & 0.20 & & 0.09 & -0.02 \\
\hline Currently in school & & & n.a. & & $-2.59 * * *$ & $-2.56^{* * *}$ & & -0.39 & -0.29 \\
\hline Father lives in household & & & -0.70 & & & -0.29 & & & -0.17 \\
\hline $\begin{array}{l}\text { Father completed more } \\
\text { than primary school }\end{array}$ & & & -0.09 & & & 0.18 & & & -0.25 \\
\hline $\begin{array}{l}\text { Lived entire life in } \\
\text { Allahabad }\end{array}$ & & & -0.08 & & & $-1.91 * *$ & & & 0.09 \\
\hline Number of siblings & & & -0.08 & & & 0.00 & & & 0.15 \\
\hline $\begin{array}{l}\text { Scheduled tribe (vs. } \\
\text { scheduled caste) }\end{array}$ & & & $\mathrm{b}$ & & & -0.60 & & & -8.37 \\
\hline $\begin{array}{l}\text { Other "backward" Hindu } \\
\text { caste (vs. scheduled } \\
\text { caste) }\end{array}$ & & & -0.22 & & & $-0.81 * *$ & & & 0.44 \\
\hline $\begin{array}{l}\text { High caste Hindu (vs. } \\
\text { scheduled caste) }\end{array}$ & & & 0.21 & & & -0.16 & & & -0.61 \\
\hline $\begin{array}{l}\text { Other religious group (vs. } \\
\text { scheduled caste) }\end{array}$ & & & 0.16 & & & -0.39 & & & $1.67 *$ \\
\hline SES low-middle (vs. low) & & & -0.05 & & & -0.23 & & & 0.47 \\
\hline SES middle (vs. low) & & & -0.19 & & & -0.62 & & & 0.63 \\
\hline SES high-middle (vs. low) & & & 0.92 & & & -0.07 & & & $1.06^{*}$ \\
\hline SES high (vs. low) & & & 1.38 & & & -0.80 & & & 0.87 \\
\hline $\begin{array}{l}\text { Constant } \\
\text { (N) } \\
\text { F-statistic }\end{array}$ & $\begin{array}{l}-0.17 \\
(204)\end{array}$ & $\begin{array}{c}0.82 \\
(204)\end{array}$ & $\begin{array}{c}1.80 \\
(197)\end{array}$ & $\begin{array}{c}3.33 * * * \\
(239)\end{array}$ & $\begin{array}{c}4.66^{* * *} \\
(239)\end{array}$ & $\begin{array}{c}7.15^{* * * *} \\
(234)\end{array}$ & $\begin{array}{l}-1.23 * * * \\
(239)\end{array}$ & $\begin{array}{l}-1.68 \\
(239)\end{array}$ & $\begin{array}{l}-1.17 \\
(234)\end{array}$ \\
\hline R-squared ${ }^{\mathrm{a}}$ & 0.0165 & 0.038 & 0.0782 & 0.0255 & 0.0795 & 0.0935 & 0.0262 & 0.0326 & 0.1028 \\
\hline Log likelihood & -135.5628 & -132.6017 & -122.989 & -547.934 & -517.574 & -498.707 & -136.388 & -135.487 & -122.634 \\
\hline
\end{tabular}

n. $\mathrm{a} .=$ not available. $\mathrm{RH}=$ reproductive health

$* \mathrm{p} \leq 0.05 ; * * \mathrm{p} \leq 0.01 ; * * * \mathrm{p} \leq 0.001$.

a = Adjusted R-squared used for linear regressions; pseudo R-squared used for logit regressions. Please see Table 8 for regression type.

$\mathrm{b}=$ Variable predicts failure perfectly. 


\section{POLICY DIVISION WORKING PAPERS}

If still in print, single copies of up to three working papers from 1989 through 2003 are available free of charge.

Beginning with the 2004 issues, the working papers will no longer be available in print format. Instead they will be distributed electronically. As each new paper is completed subscribers will be notified by e-mail and a link to the paper will be provided.

To subscribe to the Policy Research Division working paper e-mail notification list, or to obtain back issues from 1989 to 2003, please send your request to prdwp@popcouncil.org.

PDFs of recent issues are available at www.popcouncil.org/publications/wp/prd/rdwplist.html

2004

194

Barbara S. Mensch, Monica J. Grant, Mary P. Sebastian, Paul C. Hewett, and Dale Huntington. "The effect of a livelihoods intervention in an urban slum in India: Do vocational counseling and training alter the attitudes and behavior of adolescent girls?"

193 Amanda Ritchie, Cynthia B. Lloyd, and Monica Grant. "Gender differences in time use among adolescents in developing countries: Implications of rising school enrollment rates."

192 John Bongaarts. "Long-range trends in adult mortality: Models and projection methods."

191 John Koku Awoonor-Williams, Ellie S. Feinglass, Rachel Tobey, Maya N. Vaughan-Smith, Frank K. Nyonator, Tanya C. Jones, and James F. Phillips, "Bridging the gap between evidence-based innovation and national healthsector reform in Ghana."
190 Kelly Hallman, "Socioeconomic disadvantage and unsafe sexual behaviors among young women and men in South Africa."

189 Toshiko Kaneda, Zachary Zimmer, and Zhe Tang, "Differentials in life expectancy and active life expectancy by socioeconomic status among older adults in Beijing."

188 Cynthia B. Lloyd and Monica J. Grant, "Growing up in Pakistan: The separate experiences of males and females."

187 Zachary Zimmer, Xianghua Fang, Toshiko Kaneda, Zhe Tang, and Julia Kwong. "Trends and transitions in children's coresidence with older adults in Beijing municipality."

186 Sajeda Amin and Alaka M. Basu.

"Popular perceptions of emerging influences on mortality and longevity in Bangladesh and West Bengal."

185 John Bongaarts. "Population aging and the rising cost of public pensions."

\footnotetext{
* No longer available as a printed publication. Download electronic file from Web site only.
} 
184

Mark R. Montgomery and Paul C.

Hewett. "Urban poverty and health in developing countries:

Household and neighborhood effects.

2003

183 Agnes R. Quisumbing and Kelly Hallman. "Marriage in transition: Evidence on age, education, and assets from six developing countries."

182 Paul C. Hewett, Barbara S. Mensch, and Annabel S. Erulkar, "Consistency in the reporting of sexual behavior among adolescent girls in Kenya: A comparison of interviewing methods."

181 Zachary Zimmer, Linda G. Martin, and Hui-Sheng Lin, "Determinants of old-age mortality in Taiwan."

180 Frank K. Nyonator, J. Koku Awoonor-Williams, James F. Phillips, Tanya C. Jones, and Robert A. Miller, "The Ghana Community-based Health Planning and Services Initiative: Fostering evidence-based organizational change and development in a resourceconstrained setting."

179 John Bongaarts and Griffith Feeney, "Estimating mean lifetime."
178 Elizabeth F. Jackson, Patricia Akweongo, Evelyn Sakeah, Abraham Hodgson, Rofina Asuru, and James F. Phillips, “Women's denial of having experienced female genital cutting in northern Ghana: Explanatory factors and consequences for analysis of survey data."

177 John Bongaarts, "Completing the fertility transition in the developing world: The role of educational differences and fertility preferences."

176 Cynthia B. Lloyd and Paul C. Hewett, "Primary schooling in sub-Saharan Africa: Recent trends and current challenges."

175 James F. Phillips, Tanya C. Jones, Frank K. Nyonator, and Shruti Ravikumar, "Evidence-based development of health and family planning programs in Bangladesh and Ghana."

174 Geoffrey McNicoll, "Population and development: An introductory view."

173 Paul Demeny, "Population policy: A concise summary."

172 Zachary Zimmer, Napaporn Chayovan, Hui-Sheng Lin, and Josefina Natividad, "How indicators of socioeconomic status relate to physical functioning of older adults in three Asian societies."

171 Sajeda Amin and Nagah H. AlBassusi, "Wage work and marriage: Perspectives of Egyptian working women."

\footnotetext{
* No longer available as a printed publication. Download electronic file from Web site only.
} 
170 Ravai Marindo, Steve Pearson, and John B. Casterline, "Condom use and abstinence among unmarried young people in Zimbabwe: Which strategy, whose agenda?"

169 Zachary Zimmer and Julia Dayton, "The living arrangements of older adults in sub-Saharan Africa in a time of HIV/AIDS."

168 Paul C. Hewett, Annabel S. Erulkar, and Barbara S. Mensch, "The feasibility of computerassisted survey interviewing in Africa: Experience from two rural districts in Kenya."

2002

167* Dominic K. Agyeman and John B. Casterline, "Social organization and reproductive behavior in southern Ghana."

166* Carol E. Kaufman and Stavros E. Stavrou, " 'Bus fare, please': The economics of sex and gifts among adolescents in urban South Africa."

165 Kelly Hallman, Agnes R. Quisumbing, Marie Ruel, and Bénédicte de la Brière, "Childcare, mothers' work, and earnings: Findings from the urban slums of Guatemala City."

164 Cynthia B. Lloyd, Cem Mete, and Zeba A. Sathar, "The effect of gender differences in primary school access, type, and quality on the decision to enroll in rural Pakistan.”
163 Barbara S. Mensch, Wesley H. Clark, and Dang Nguyen Anh, "Premarital sex in Vietnam: Is the current concern with adolescent reproductive health warranted?"

162 Naomi Rutenberg, Carol E. Kaufman, Kate Macintyre, Lisanne Brown, and Ali Karim, "Pregnant or positive: Adolescent childbearing and HIV risk in South Africa."

161 John Bongaarts, "The end of the fertility transition in the developing world."

160* Julia Dayton and Martha Ainsworth, "The elderly and AIDS: Coping strategies and health consequences in rural Tanzania."

159 Carol E. Kaufman, Shelley Clark, Ntsiki Manzini, and Julian May, "How community structures of time and opportunity shape adolescent sexual behavior in South Africa."

158 Geoffrey McNicoll, "Demographic factors in East Asian regional integration."

157 Zachary Zimmer and Sovan Kiry Kim, "Living arrangements and socio-demographic conditions of older adults in Cambodia."

156 John Bongaarts and Griffith Feeney, "How long do we live?"

155 Zachary Zimmer, Linda G. Martin, and Ming-Cheng Chang, "Changes in functional limitations and survival among the elderly in Taiwan: 1993, 1996, and 1999."

\footnotetext{
* No longer available as a printed publication. Download electronic file from Web site only.
} 